\title{
11 Eylül Sonrası ABD’nin Irak İşgali Sürecinde Hegemonya-Emperyalizm Tartışmalarına Eleştirel Bir Bakış
}

\author{
A Critical Approach To The Hegemony-Imperialism Discussion \\ During The Irak Invasion Period After September 11
}

\author{
Murat ALAKEL* \\ Ahmet Safa YILDIRIM ${ }^{* *}$
}

\section{Özet:}

Bu makale kısaca 11 Eylül sonrası ABD'nin Irak müdahalesiyle gündeme gelen hegemonyaİmparatorluk tartışmalarını teorik açıdan ele almaktır. Öncelikle hegemonya ve Emperyalizm kavramlarının terminolojik tanımları yapılmıştır. Sonrasında uluslararası sistemde bu kavramlar hakkındaki farklı teorik yaklaşımlar özetlenmiştir. Üçüncü olarak ABD’nin hegemonyasının kurulum süreci tarihsel açıdan ele alınmış ve ABD'nin Irak müdahalesi hukuki ve uluslararası siyaset açısından incelenmiştir. Arkasından işgal sürecinde gündeme gelen hegemonyaimparatorluk tartışmaları incelenmiştir. Bu makalenin yazılmasında tanımlayıcı, açıklayıcı, karşılaştırma yöntemlerinden yararlanılarak farklı tarihsel dönemleri kapsayan argüman ve Uluslararası İlişkiler teorilerden yararlanılmaya çalışılmıştır. Çalışmada ayrıca ABD'nin ulusal güvenlik stratejileri, önleyici müdahale-savaş gibi uluslararası istikrar, barış ve sistemi tehdit eden kısmen hegemonik krizler ve tek taraflı müdahaleler de tartışılmaktadır.

Anahtar Kelimeler: Hegemonya, Emperyalizm, Amerikan Müdahalesi, Irak Savaşı, Önleyici Savaş, Tek Tarafılık.

\section{Abstract:}

In that article, we have elaborated the theoretical aspects of the hegemony-empire discussion about the US intervention into Iraq after the September 11 attack. Firstly, we have tried to define both the concept of hegemony and empire with the resourceful terminology. Secondly, it is delineated within the various theoretical comparative perspectives about hegemony-Imperialism relations in the international system. Thirdly, there also analyzed the US intervention into Iraq

* Yrd.Doç.Dr., Yalova Üniversitesi, Uluslararası İlişkiler Bölümü, muratalakel@,hotmail. $\underline{\text { com }}$

** Araştırma Görevlisi, Yalova Üniversitesi, Uluslararası İlişkiler Bölümü, ahmetsafa22@,hot$\underline{\text { mail.com }}$ 
in 2003 from the legal and International political contexts. Later, the repercussion effects into hegemony-neo-empire disputes in the international system. The subject matter investigated through using definitive, explanatory, discursive methodology with including different historical era and IR theories. There are also given more details on the US strategies such as unilateral preemptive wars which could destabilize international peace, stability and system by creating hegemonic crises. ralism.

Keywords: Hegemony, Empire, US Intervention, Iraq War, Preemtive War, Unilate-

\section{Giriş:}

Hegemonya kavramına akademik ilgi “ABD Hegemonyasının” düşüşe geçtiği 1970'li yıllarda artış göstermiş, dünyada meydana gelen farklı gelişmelere paralel olarak kavramın da içeriği tartışılır hale gelmiştir. Bu yıllarda ABD'nin hegemonyasını tesis etme sürecinde rıza unsuruna yapılan vurgu bu kavramın klasik hegemonya-imparatorluk kavramlarından ayrıştıran en önemli nokta olmuştur. Kısaca bu çalışma 11 Eylül sonrası ABD'nin dış politikasında meydana gelen köklü değiş̧iklikler sonrası gerçekleştirilen Irak işgalini bu kavramsal tartışma çerçevesinde inceleyecektir.

Çalışmanın ilk kısmında hegemonya ve imparatorluk kavramlarının terminolojik incelemesi yapılmıştır. Akabinde ABD‘nin tarihsel süreç içerisinde hegemonyasını nasıl kurduğu incelenmiş ve hegemonya ile imparatorluk arasındaki farklılaşan ilişkiler anlamlandırılmaya çalışılmıştır. Çalışmanın ilerleyen kısımlarında ABD'nin söz konusu Irak müdahalesinin uluslararası hukuk ve siyaset açısından incelemesi yapılarak müdahalenin emperyalizmhegemonya tartışmaları içerisindeki konumu belirlenmeye çalışılmıştır.

\section{Hegemonya ve Kavramsal Çerçeve}

Hegemonya, terim olarak sözlükte, herhangi bir devletin diğer bir devlet üzerinde kurmuş olduğu siyasal üstünlüğü, ve bu ülke üzerindeki bask1s1 anlamına gelmektedir. Kelime olarak ise Türkçede, üstünlük, egemenlik, hakimiyet ve aynı şekilde hegemonya olarak ta kullanılmaktadır. Kavram, köken olarak Yunanca olmakla birlikte, "kuvvetle ve kıymetli vasıflarla üstünlük ve bir devletin diğer bir ülke üzerindeki siyasi etkinliği ve baskısı" manasına gelmektedir. Benzer şekilde, uluslararası sistemde bir devletin tek başına uluslararası ekonomik, askeri ve siyasi konularda kural ve normları üstün hakim gücünü bölgesel ve küresel ölçekte sürdürebilmek için koymasıdır (Goldstein\&Pevehouse, 2013, ss.58). Robert O. Keohane hegemonyay1, bir devletin devletler arasındaki ilişkileri belirleyen kuralları muhafaza edebilecek kadar güç sahibi ve bunu istekli bir şekilde yapma durumu olarak tanımlamaktadır. (Keohane, , 1984, s.34). Hegemonia, kelimesi Yunanca 'liderlik' 
etme anlamina gelirken, terim olarak ise sosyal grup, birey ya da devletlerin diğer grup ve devletler üzerindeki maddi ya da soyut etki ve yönlendirici üstünlük anlamındaki liderlik etmesini ifade etmektedir (Yetiş, 2012, s.87). Dolayısıyla, uluslararası ilişkilerde hegemon kendi aralarında siyasi olarak sosyal bir düzende hiyerarşik, yapılandırılmış bir güç, kaynak, çıkar oluşturmuş bir devletler sistemine liderlik eden ülke olarak anlamlandırılmaktadır (Griffiths\&O'Callaghan, 2004, ss.137). Bu yapı içindeki diğer devletler ise hegemonu ve onun güdümündeki sistemi kabul etmek ya da hegemona ve sisteme muhalefet etmek arasında kendini konumlandırmak durumundadır. John J. Mearsheimer'e göre bir hegemonun en temel amacı, kendi hegemonyasını inşa ederken, onun hegemon statüsüne muhalefet edebilecek rakip bir büyük gücün başka bir bölgede hakimiyet kurmasını önlemektir (Mearsheimer, 2001, s.1). Robert Gilpin'e göre ise bir hegemon güce sahip devlet, hakimiyeti altındaki uluslararası ekonomi-politik yapıyı ona karşs kendisini düşman ilan etmiş muhaliflerinden gelecek saldırılardan koruyabilmek için yeterli askeri gücü elinde bulundurmas1 gerekir. Tek kutuplu bir uluslararası sistemde bir devletin çok üstün bir güce sahip olması durumunda bu devlete hegemonik devlet denmektedir (Kaarbo\&Ray, 2011, s.187). Tarihsel süreç içerisinde hegemonik güçler sadece dünya ölçeğinde bir savaştan sonra ortaya çıkmışlardır ve bir hegemonik savaşın sonucu bir diğer büyüme, yayılma ve sonuçta gerileme döngüsünün başlangıcıdır (Gilpin, 1998, s.203). Devletlerin egemenlik yetkisi kendi topraklarında üstün otorite olarak tanınmasına rağmen uluslararası sistemde "hiyerarşik bir düzen" sağlayan daha güçlü devletlerin baskın ve hegemon güç olduklarını görebiliriz; örneğin merkantilist dönemlerde Portekiz, İspanya, Hollanda dünya güçleri iken gerçek "küresel hegemon güçler" 19. asırda İngiltere, 20. yüzyılda ise ABD'dir (Cohn, 2003, s.27).

Yaygın olarak uluslararası ilişkilerde pozitivist yaklaşımda hegemonya söylemi, bilinen bir coğrafi sahada ya da herhangi bir siyasi eylemin bir devletin öteki ülkeler üzerinde kurduğu etkisel hâkimiyeti vurgulamak amaciyla kullanılır. Bu anlamda Realist teoriye göre "hegemonya" yalnız başına nüfuzlu bir güce işaret etmektedir. Bu gücün en temel unsurları gücün, ekonomik ve askeri kapasitelerinde olduğu varsayılmakta ve uluslararas1 siyasette uluslararası toplum faktörünün etkisi ihmal edilmektedir (Su, 2006). "Tahakküm" terimi ile aynı manada kullanılan realist hegemonya terimi, "tahakküm-baskı" altında olan devletlerin, Hegemon'a verdikleri "rızanın oluşturulmasını" tek taraflı bir şekilde dikkate almamaktadır. Bu yönüyle hem realist hem de liberal teoriler hegemonya kavramını devlet eksenli ele almışlardır. Oysa, hegemonya terimini Neo-Marksist teoriler "farklı sınıf bağlantılı güçlerin, belirli bir s1nıfın ya da fraksiyoner grubun politik, entelektüel ve ahlaki söylemin liderlik ve de örgütlenmesini” (Jessop, 2008, ss.279) savunur. 
Yapısal Realizm ve Realizm teorisinin ABD'de popüler olması bağlamında Vietnam ve 2003 Irak işgalleri bu çerçevede eleştirilmiştir. Amerika'da önde gelen Realist yazarlar tarafindan ilk olarak ABD'nin dünya politikasında siyasi liderliğini sürdürebilmesi için, klasik ve yapısal realizm dinamik anarşik uluslararası sistemde statüko ve güçler dengesini koruyan rasyonel teoriler olarak görülmüştür. 1970'li yıllarda ise realist yazarların temel öncelikleri, uluslararası siyasette (Arap-İsrail Savaşı, Petrol/Borç Krizleri, Vietnam Savaş1 ve yumuşama dönemi) ABD ve Batı ekonomisinde-Bretton Wood Sistemin sarsılması-Doların devalüasyonla dalgalı kura geçmesi-istikrarsılı̆ğa neden olan krizler bağlamında ABD'nin hegemonik öncülügünü daha risksiz yönetmesi ve güç yozlaşmasının hegemonik krize dönüştürmeden önleyici denge politikaları (Komünist Çin'in tanınması) için farklı açılım politikaları olmuştur. Bu yönüyle Yapısal Realizmde, sistem, yapı, devlet, birim, güçler dağılımı ve çeşitli sistem analizleri yapılarak devletlerin işlevsel güçlerini farklı uluslararası sistemin anarşik doğasına yönelik rasyonel uyumunu bilimsel çerçeveye oturtmak istenmiştir. Bu çerçevede realist ve liberal söylemleri savunan teorisyenler, aynı zamanda realizm ve liberal teorinin kısmen bileşimi olan Neo-liberal teorinin gelişimine büyük katkı yapmışlardır. Neo-liberalizm, anarşik uluslararası sistemde rasyonel, üniter, çıkarc1, realist devletler güvensizlik, belirsizlik, otonomi, aldatma ve diplomatik pazarlık, göreceli kazanç risklerine rağmen birbirleriyle mutlak ve ortak kazanç ve çıkarlarını geliştirmek ve korumak için ortak uluslararası örgüt, kurum, rejim kurarak karş1lıklı bağımlığı geliştirmekten, hatta bu sürecin hegemonik bir gücün istikrarıyla oluşturulmasına bile razı olmuşlardır, görüşünü savunur (Folker, 2013, ss.114). Burada Neorealizm ile Neoliberal teorinin birbirinden fark1 esasında ikincisinin uluslararası işbirliklerinin nitelik ve nicelik olarak örgütler kanalıyla kolaylaştırılıp devletler arasında bir rejim oluşturacak düzeye gelmesidir (Richardson, 2010, s.223).

Aynı şekilde diğer bir teori "Hegemonik İstikrar Teorisi” (HİT)'nin genel argümanı "anarşik bir uluslararası sistemi yapılandırarak kuralları uygulayan çok üstün bir aşkın yetkisi olan hegemon bir gücün olmasıdır" (Kaarbo\&Ray, 2011, s.192). Hegemon, uluslararas1 sistemde sanki merkezi hükümet gibi kısmen bir düzen kurar: anarşik belirsizliğin azalması, saldırıyı caydırma, serbest ticaretin teşviki, standart bir finansal kur sistemi kurulması gibi ayrıca hegemon güç orta ve küçük devletler arasındaki sorunları da çözebilir (Goldstein\&Pevehouse, 2013, s.59). Hegemonik istikrar teorisi açı ve istikrarlı bir uluslararası ekonomik sistemin, tek bir hegemon gücün yeterli kaynak ve liderlik becerisini sergileyerek bir liberal ekonomik düzeni kurabilmesini öngörür (Cohn, 2003, s.27). Keohane'a göre ise iki temel varsayımı vardır: İlk olarak dünya politikasında düzen tek bir baskın güç tarafından yaratılır. 
İkinci olarak düzenin devamı ve korunması bu hegemonyanın devamına bağlıdır. Hegemonik istikrar teorisi özellikle son iki hegemonik güç olan Büyük Britanya ve ABD'nin konumları üzerinden şekillendirilmiştir ve bu teoriye göre dünya ekonomisi ve siyasetindeki düzen tek bir baskın gücün varlığı tarafindan yaratılır (Keohane, 1984, s.31). Fakat bu düzen, rejim ve kurumlar oluşturulduktan sonra işlevsel olarak etkin olması sonrası süreçte Hegemon güce ihtiyaç olmayabilir yaklaşımları da vardır. Gilpin ise Hegemon bir gücün liberal dünya ekonomik düzeni için gerekli olduğunu ama yeterli olmadığına vurgu yaparak esas hegemon gücün İngiltere ve Amerika örneklerinde olduğu gibi bu devletlerin uluslararası işbirliklerini kolaylaştırarak liderlik ettiğine; Oysa hegemonun, Almanya, İtalya, Japonya, SSCB gibi emperyal bir güce, zora ve şiddete dayandığında başarısız olacağını belirtir (Gilpin, 2001, ss.93-97). Bunun yanında 1970'lerde Amerikan'in hegemon gücü sarsılmaya başladığında kamuoyunu rahatlatmak, gerek HİT gerekse Rejim teorilerinin uluslararası hukuk, örgütler, normlar, kurallar ve değerlerin evrensel hale geldiği dolayısıyla liberal siyasi ve ekonomik düzenin devam edeceği türü eklektik yorumları eleştiren Susan Strange'e göe, Amerika'nın diğer klasik imparatorluk ve devletlerden farklı olarak birincil, yapısal, kurumsal esas güç olarak güvenlik, üretim, finansal, bilgi yapılarında özel-kamu, bireyselkollektif, ulusal-uluslararası ölçekte küresel ekonomi, devletleri, kurumları sadece içerik ya da gündem değil yani onları şekillendirme, yapılandırma, belirleme, kontrol ve hakimiyeti olduğu dolayısıyla konjektürel güç ilişkisini yansıtan taktiksel ya da ikincil düzeyde güç yapılarını ve alanları güncel ilişkiler gücünün göreli etkisizliği yanılsamaya neden olabilir (Strange, 1994, ss.23-119). Strange göre, Amerika'nın hegemonik güç olarak çöküşünü vurgulayan yaklaşımların (Amerikanın gücü azalıyor, Büyük Güçlerin kaçınılmaz çöküşü ve ABD'nin çöküşü uluslararası sistemde siyasi ve ekonomik istikrarsızlığı getirecek) gerçeği yansıtmadığını çünkü Amerika klasik toprak eksenli devlet ve sistemlerden farklı olarak yapısal gücünün güvenlik, üretim, finansal, bilgi gibi temel alanlarda teknoloji ve yeniliklerde etkinlik, üretkenlik, verimlilikte değişime uyumda küresel ve ulus-ötesi ölçekte askeri, ekonomik, siyasi, sosyal, kültürel alanlarda öncülük-liderlik etmektedir (Strange, 2006, ss.352-358).

Hegemonya kavramının disiplinde kullanımı aynı zamanda post-pozitivist ve post-yapısal yaklaşımları da kapsamaktadır. Robert Cox ise hegemonyayı, "belli bir güç yapısının geçici biçimde evrenselleştirilmesi sureti ile bir domine eden bir olgu gibi değil, fakat doğanın gerekli düzeni olarak görüldüğü sistemik ve hegemonik gü̈ç" şeklinde aktarır ( $\mathrm{Su}, 2006$, s 22). Cox, Hegemonya'nın özünde uygun güç, düşünceler ve kurumsal yapıları oluşturarak istikrarlı bir düzenin oluşması için teorik olarak devletin uluslararası 
sorunları çözmesi için baskın olmasını vardır. Cox, klasik teorileri belirli dönem ve düşüncelerin konjektürel yansımalarını, belirli bir çerçeve ve bakıştan hakim düzenin kurumsal, sosyal ve güç ilişkilerini ve olayları çözümleme ile yetindiğini oysa gerçek teorinin geçmiş, şimdi ve gelecekle ilgili olarak yap1sal anlamda değişimi de dikkate alarak düşünce, fikir ve ideolojinin şekillendirdiği; dolayısıyla güç yapılarının ve onların kurumsal yapıları gerçekte sosyal güçlerin etkileşim modeli aynı zamanda devlet formlarını ve nihayetinde hakim dünya düzenini oluşturduğunun farkında olarak açıklamaktadır. Aynı şekilde, Cox günümüzde sosyal güçlerin sınırları aşarak devletlerin yerel ve küresel yapılar arasında otonom bir araca dönüşmesine ve devletlerin doğasının ve gücün yeniden yapılandığını belirtir (Cox, 1981, ss.126-155).

Bunun yanında, devletler ekonomik zenginlik oluşturmak için birikim stratejilerine çok önem verirler. Bu yönüyle ulusal stratejilerin küresel hegemonik stratejiyle uyumlu hale getirmek için sermaye dolaşımının makul biçimi(liberal, tekelci, tekelci devlet), sermayenin rasyonel uluslararasılaşmasının makul biçimi (bankacı, endüstriyel, ticari), ulusal firmaların dışarıda karşılaştıkları otantik uluslararası tutum, ülkenin içeride ve dışarıdaki bağımlı ya da bağımsız ekonomik, toplumsal ve siyasi güçler dengesinin yanında ulusal ekonominin ve küresel sahadaki üretim potansiyeli için gerekli stratejik manevralar çok önemlidir (Jessop, 2008, ss.269-270). Dolayısıyla bu süreçte hegemonik projeler ekonomik birikim stratejileriyle uyumlu örtüşmesi onları sürdürülebilirlik bağlamında güvenli yapar; fakat hegemonya "askeri başarı, siyasi istikrar, toplumsal reform, ekonomik, sivil toplum, devlet yapilar1 ya da ahlaki yenilenme" gibi farklı amaç ve gayelerden dolayı kısa vadede ikinci stratejiyle çelişebilir (Jessop, 2008, ss.279-280). Ülkelerin sosyal sermaye yapılarının ülke içi ve dışı bireysel ve kurumsal organizasyon kapasiteleri de önemlidir. Dolayısıyla bir süper gücün genelde bir bölgenin ekonomik ya da siyasi olarak sistem kurularak düzenlenmesi için baskın bir liderlik gereklidir. Realist söylemde bu özel olarak büyük güçlerin sistemde diğer ülkeler üzerindeki etkisi liderlikten denetime kadar varan güç ve kontrolünün kullanılmas1dir (Baylis\&Smith, 2006, ss.95).

Gramsci, hegemonya kavramını klasik tanımlamalardan farklılaştıran ve üstün kılan unsur kavramın "hâkimiyet ile rızayı" birleştirmesidir (Kurtbağ, 2007). Sert güç veya tahakküme dayalı olan klasik hegemonyanın aksine, Gramsci'ci hegemonya, hegemonyayı yalnızca somut anlamda değil, aynı zamanda fikirsel bir eylem süreci olarak da anlamlandırarak geleneksel anlayışa kıyasla daha geniş bir perspektif sunar. Bu yaklaşımın en çarpıcı yönü, hegemonun üzerinde etki oluşturmak istediği devletlerin rızasını almak zorunda oluşudur. Bu noktada vurgulanması gereken, hegemonun maddi gücü her ne kadar hegemonyanın oluşumu için gerekli olsa da hegemonyanın sürdürüle- 
bilmesi açısından bu maddi gücün tek başına yeterli olmadığıdır. Diğer bir ifadeyle, hegemonyanın realist teorideki gibi yalnızca tahakküme bağlı bir güç ilişkisinden ibaret olmadığı, aynı süreçte etik ilkeler doğrultusunda sağlanan rıza ilişkisidir. Bu hegemonyanın elde edilmesi rızanın kazanılması için oluşturulan yaklaşımların ne ölçüde ön plana çıkacağı ile doğru orantılıdır. Diğer bir yönüyle bu tarz bir yapıda hegemonik krizler ortaya çıkabilir ve bu hegemonik güç, karşıt bir hegemonik gücün ortaya çıkmasıyla kaybedilebilir. Gramsci karşıt hegemonik gücün somut ve ideolojik faktör ile beraber öncelikle insanların zihinlerinde yer edindiğini söyler. Karşı hegemon güç, mevcut hegemon güce kıyasla daha az kapasiteye sahip bir gücün kaynaklara daha kolay ulaşması neticesinde ve ayrıca mevcut hegemonik gücün meşruluğuna meydan okumasının sonucunda hegemon güç pozisyonuna erişebilecektir (Cox\&Jacobson, 1977, ss. 127).

Rıza, düzenin tekrardan oluşturulması noktasında önemli bir role sahip olabilir. Rızayı kazanmak amacı ile hegemonik güç diğer devletlere karşı ortak bir dil üretmek durumundadır ve bu dil vasıtasıyla kuracağ 1 iletişim sonucunda hegeomonik güç ideolojisini yaymaya ve diğer devletleri kendi çıkarları yönünde etkilemeye çalışır. Joseph Nye'a göre somut kaynakların kontrolü vasıtası ile kazanılan sert güç, başkalarının davranışlarını şekillendirme yeteneği iken; askeri ve ekonomik unsurlardan oluşan sert gücün aksine zorlama veyahut teşvik içermeyen Yumuşak güç ise başkalarının davranışlarından evvel isteklerini şekillendirme kapasitesidir. Dolayısıyla yumuşak ve sert güç aynı şey olmamakla birlikte birbiriyle ilişkilidir. Çünkü bu hegemon gücün maddi başarısı bir kültür ve ideolojik çekim alanı oluşturur iken ekonomik ve askeri başarısızlıklar ise kendinden şüphe ve kimlik krizine sebep olur (Nye, 2003a, s.60). Nye, yumuşak gücü; "Şayet istediğim şeyi senin de istemeni sağlayabilirsem, o zaman yapmak istediğin şeyi yapmaya seni zorlamama gerek yoktur." şeklinde tanımlar. Bu anlamıyla Yumuşak Güç'ün, devletin, milli menfaatlerini, liderlik etmiş olduğu ülkelerin menfaatleriyle uyumlaştırabilme ve söz konusu ülkelerin bu çıkarların içselleştirilmesine etki edebilme kapasitesi olduğunu söyleyebiliriz (Nye, 2003b, s. 10- 11). Bu kapasiteye iki örnek verecek olursak, ilk örneği İkinci Dünya Savaşını takip eden süreçte ABD'nin komünizme karşı liberal ve demokratik yönetim şeklinin avantajları üzerinde durması oluştururken, diğer örneği ise Soğuk Savaş sonrası süreçte literatürde yer adlığı şekli ile liberalizmin galibiyeti ve serbest piyasa ekonomisinin üstünlügüne yapılan vurgu oluşturmaktadır. Hegemon gücün oluşturduğu küresel dil vasıtasıyla kendi ideolojisini kesintisiz yaymak zorunda olduğunu, aksi takdirde rızayı sağlama hususunda güçlük çekebileceğini ve bu durumda karşı hegemonik oluşumların ortaya çıkabileceği önceki kısımlarda belirtilmişti. Örneğin II. Dünya Savaşı sonrası süreçte 
SSCB'nin yumuşak gücü dünyada oldukça etkili iken 1956 Macaristan ve 1968 Çekoslovakya işgalleri bu ince gücü ve prestijini oldukça sarsmıştır (Nye, 2003a, s.62). Aynı şekilde ABD'nin 2003 Irak ile Rusya'nın Gürcistan ve Ukrayna'ya tek taraflı askeri müdahaleleri bu iki ülkenin gerek bölgesel gerekse uluslararası toplum nazarında hegemonik sert gücün kullanılmasına karşı tepki doğmuştur.

Hegemonyanın ortaya çıkışı ilk kez devletlerarası ilişkiler çerçevesinde gerçekleşse de, hegemonya kavramının modern sosyal bilimler literatürüne dahil olması daha çok siyaset bilimi çerçevesinde olmuştur. Kavram uluslararası ilişkiler literatürüne ise 1970'lerde girmiştir (Chase-Dunn vd, 1994, s. 373). Ancak 1950 ve 1960'lardaki düzenin hegemonik bir düzen olduğunu söyleyebiliriz. ABD Soğuk Savaş sonrası dönemde ülke içerisindeki endüstriyel kapasitesi ile küresel düzeyde ideolojik söylemlerini eklemleştirmeyi başarmış ve batı bloğunun oluşmasında etkin rol oynayarak batı ittifakına dahil olan ülkelerin rızalarını sağlama hususunda liderlik becerisi gösterebilmiştir. Bunun sonucunda söz konusu blokta hegemon konumuna erişebilmiştir (Eralp, 2005, ss.158). Fakat 1970'lere gelindiğinde ABD'nin bu hegemonik gücünde gerileme görülürken hegemonya kavramı çok daha fazla tartış1lır hale gelmiştir. Bu tartışmalarda öne çıkan konular hegemonya sonrası uluslararası sistemde istikrarın nasıl sağlanacağına yönelik uluslararası rejimlerin rolleri ve hegemonyanın etik ve ilkesel anlamda kendisine yapılan eleştiriler olmuştur.

\section{ABD'nin Hegemonyasının Kurulum Süreci}

ABD, Uluslararası ilişkilerde, Dünya Savaşlarını saymazsak klasik Avrupa Emperyal devletleriyle karşılaştırıldığında Afro-Avrasya coğrafyasında nispeten algılarda liberal barışçıl bir özgürlükler ülkesi olarak algılanır. Oysa $\mathrm{ABD}$, kuruluşundan bu yana coğrafi, siyasi, askeri ve ekonomik olarak hem bölgesinde hem de küresel ölçekte sürekli çatışma ve yayılma halinde olan bir ülkedir. Örneğin, Küba Krizi esnasında, Bakan Dean Rusk'ın sunduğu raporda ABD'nin 1798-1895 yılları arasında en az 103 kez, 4 kıtada, farklı ülkelerin içişlerine siyasi ve ekonomik çıkarlarını korumak için askeri müdahalede bulunduğunu aktarır (Zinn, 2005, s.316). Meksika ve İspanyollarla savaşlarını saymazsak, Monroe Doktrinin de olduğu gibi ABD genelde klasik Avrupa türü İmparatorluk kurma anlayışını yansıtan kolonicilik kültüründen farklı olarak Amerikan tüccar ve mallarının özgürce girebildikleri müddetçe sömürge ya da fetih savaşları yapmıyordu; Kısaca, kendisi için bir Serbest Pazar anlayışını önceleyen bir "Açık Kapı” politikasını dünyanın her yerinde XX. Yüzyılda da savunmuştur (Zinn, 2005, s.320). H. Kisserger, ABD'nin XX. Yüzyılda, 
uluslararası ilişkilerde dünyayı en çok etkileyen ülke olarak, hem devletlerin içişlerine karışmama ilkesini savunduğunu hem de kendi değerlerinin bütün dünyaca uygulanmasını, diplomaside pragmatik, etik ve ahlaki davranışların ideolojik savunulması, birçok ülke ile çok farklı konularda anlaşma yaparak fazla yükümlülüklere girme-bazen bu yükümlülüklerden kaçınma, demokratik değerleri, hukuk devleti, insan hakları ve serbest piyasa düzenini en iyi uygulayan ülke olma ve bu değerleri: demokrasi, serbest piyasa ve uluslararasi hukuka uymayı amaçlayan bir küresel düzeni herkese empoze etmek isteyen idealist başkanlara sahip olduğunu belirtmiştir (Kissenger, 2011, ss.9-10).

ABD, II. Dünya Savaşı'ndan herhangi bir darbe almadan ve buna ek olarak bu süreçten daha da gelişip zenginleşerek çıkan yegane devlet olmuştur. Rakipsiz askeri ve endüstriyel üretim kapasitesinden elde ettiği güçlü para birimi, savaş sırasında geliştirip Japonya’ya karşı kullanmış olduğu nükleer gücü, liberal-demokratik değerlere vurgu yapan ideolojik avantajı ile dünya üzerinde Büyük Britanya'nın sahip olduğu hegemonik güç ve konuma benzer bir şekilde sahip olmuştur. ABD, İngiltere'nin tecrübesine dayanarak belirlemiş olduğu ulusal çıkarlarını evrensel çıkarlar olarak deklare etmiş ve bu temelde hegemonik konuma erişimini meşrulaştırmak istemiştir.

Yeni bir hegemon devlet olarak ABD'nin İngiltere'den fark1 hegemonik gücünü kendi öncülüğünde dünyanın ekonomik, siyasi ve güvenlik sistemini şekillendirmek üzere inşa ettiği örgütler vasıtasıyla uygulama imkanına sahip olmasıdır. Hegemonik koalisyonu etki alanı içerisindeki gruplardan sağladığı "rıza"yı da bu kurum ve rejimlerin iç mekanizmalarında karar verme süreçleri içerisinde oluşturmuştur.

ABD İkinci Dünya Savaşı sonrası kurmuş olduğu hegemon yapı ile, edinmiş olduğu Fordist birikim rejimi ve Keynesçi ekonomik model çerçevesinde oluşan üretkenliğe ve büyümeye dayalı bir misyonu temel almıştır. ABD’nin bu noktada sergilemiş olduğu ciddi ekonomik performans ve bunun sonucunda oluşan refah, savaş sonrasında kapitalizmin cazibesini artırırken, komünizm gibi en ciddi ideolojik rakibinin cazibesini de azaltmıştır. $\mathrm{Bu}$ ortamda, mevcut misyon ABD'nin kurmuş olduğu yapının uluslararasılaşmasını da paralel olarak kolaylaştırmıştır. Bu uluslararasılaşma süreci, ABD'nin Marshall Planı gibi yardımlarla batı Avrupa'yı ve Japonya gibi kapitalist değerleri benimseyen devletleri liberal demokratik perspektifte yeniden yapılandırmasi ve özel sektörün de doğrudan yatırımlar yapması vasıtasıyla gerçekleşmiştir (Kurtbağ, 2007 s.63).

Amerikan devlet yöneticileri, kapitalistleri ve organize olmuş emek liderleri, ekonomik gelişimi sağlamak ve ileri gelen kapitalist güçler arasında karşılıklı bağımlılığı oluşturmak için birlikte hareket ettiler. Nitekim, savaş 
sonrası Batı'da meydana gelen konsensüste, başlıca siyasi partiler ve komünist olmayan örgütlü işgücü de antikomünizm fikrini benimsemişlerdi. ABD müttefikleriyle, Dünya Bankası, IMF, GATT, BM Konsey Veto, Truman ve Marshal kurumlarıyla kendi hegemonyası güçlendirdi (Lieber, 2005, s.42). Aynı şekilde, Bretton Woods ve BM sistemi çerçevesinde kurulan uluslararası kurum ve mekanizmalar da bir yandan ABD'nin ülke içinde kurmuş olduğu hâkim üretim tarzını (Fordizm) desteklerken, diğer taraftan da hegemonun oluşturduğu küresel normları ve fikirleri küresel ölçekte yaymaya hizmet ettiler (Kurtbağ, 2007 s.64).

İlerleyen süreçte Keynesçi refah devleti ve Fordist birikim rejimine dayalı pax-Americana'nın düşüşü, 1960'ların sonunda başlamış ve 1970'li yıllarda da söz konusu birikim rejimi ve devlet formu ciddi biçimde sarsılmıştır. Bunun başlıca nedenlerini, ülke içi ve dişındaki ekonomik kriz ortamı ve Vietnam Savaşı'nın yarattığı olumsuzluklar ile Avrupa, Japonya ve yükselen yeni güç merkezlerinin ekonomik rekabeti olmuştur.

$\mathrm{ABD}$, devam eden Vietnam Savaşı nedeniyle dünya ekonomisinde doların bollaşmasının olumsuz etkisini hissetmiş ve aşırı değerlenmiş olan dolar, Amerikan altın rezervlerini iyice azaltarak enflasyon ve devalüasyon sonucunda diş ticaret dengesini de bozmuştur. Bu gelişmeler sonucunda, Bretton Woods sistemine olan güven sarsılmış ve 1971'de Nixon yönetiminin tek yan11 bir kararla altın standardını terk etmiştir.

Ayrıca Japonya ile Singapur, Kore ve Tayvan gibi Pasifik'teki yeni büyüyen merkezler rekabet güçlerini artırmışlar hem de Almanya basta olmak üzere batı Avrupa ekonomileri artık dünya pazarlarında ABD ile rekabet etmeye başlamışlardır (Gill, 2003, s86). Buna karşın, Vietnam Savaşı'nın yaralarını sarmaya çalışan ABD'nin ekonomik ve siyasi gücünde ise göreli bir düşüş eğilimi meydana gelmiştir. Bu sürece, Arap-İsrail Savaşı, Petrol Krizi, Borç Krizleri, SSCB'nin Afganistan Müdahalesi ve İran Devrimi bölgesel ve küresel krizleri artırmıştır. Bu da savaş sonrası kapitalist ülkelerarası uzlaş1 ve işbirliği ortamının ortadan kalkmaya başladığının göstergesi olmuştur. Gramsci'ci anlamda bir hegemonya krizi olarak yorumlanan bu duruma bir son verilmesi için gereken yeni uzlaşının daha geniş tabanlı olması gerektiği ileri sürülmüştür. Bu anlamda, yeni oluşacak blok, büyük ölçüde Atlantik ulusları arasında kurulan pax-Americana döneminin aksine, bazı yeni sanayileşen ulusları, Sovyet Bloku'nun artan uluslararası rolünü, Pasifik ekseninin ve batı Avrupa'nın artan ağırlığını ve ulus aşırı sermayenin büyüyen gücünü de yansıtmalıydı (Gill, 1990). Bu açıdan bakıldığında ABD’nin II. Dünya Savaşı sonrası sistemi tek başına belirleme noktasında elde ettiği gücün bu süreçte kısmen azaldığı görülmektedir. Avrupa'da AT'nin kurulması Batıda ABD'nin hegemonik üstünlüğü sürecini elbette ciddi olarak etkilemiştir. 


\section{Hegemonya ve İmparatorluk İlişkisi}

İmparatorluk, kısaca "imparatorlukla idare sistemi yani çok geniş topraklar üzerinde kurulan hakimiyet" şeklinde kavram aktarılır (Redhouse, 1995, s.311). Emperyalizm, ise "imparatorluk sistemi, hükümeti ve sömürgecilik" anlamlarına gelir (Redhouse, 1995, s.487). Fransızca kökenli kavram "bir devletin sınırlarını genişletme politikası olarak başka memleketlerin zenginlik kaynaklarını ele geçirme ve insanlarını kendi hesabına çalıştırma" olarak belirtilir. ${ }^{1}$ Benzer şekilde Emperyalizm, "bir devletin kendi sınırları dışında yaşayan başka halklar üzerinde onların rızası olmadan denetim kurmayı amaçlayan politika" şeklinde vurgulanır. ${ }^{2}$ Emperyalizm kavramı yine "imparatorluk kurmak için yabancı bir ülkenin fetih ve yönetim uygulaması olarak açıktan küresel ilişkiler bağlamında diğer devletlerin hiyerarşi kurulması ve boyun eğdirilmesi" (Baylis\&Smith, 2006, s.774) olarak anlat1lır. Emperyal devlet ise, kendini savunamayan devlet ve halkları, askeri ve ekonomik üstünlügünden dolayı onlar üzerinde güç, prestij, stratejik avantaj, ucuz emek, doğal kaynaklar ve pazarlarına ulaşarak fayda elde eder; yöntem olarak ta askeri fetih, işgal, yerleşimci, misyoner ve Pazar hakimiyetini kullanır (Griffiths\&O'Callaghan, 2004, s.152). Emperyalizm, Marx'a göre Burjuvazinin küresel ölçekte Pazar arayışı olarak, Çin duvarını bile aşan, geleneksel Asya tarzı üretimleri modern dünyayı tek kapitalist pazar haline getirmesi olarak aktarılır (Linklater, 2012, ss.151-182). Diğer bir kaynakta "zor ya da güç kullanarak koloniler elde etmektir", Lenin Avrupalı kapitalistlerin yüksek kar elde etmek için kolonilere yatırım yaptığını bunların bir kısmıyla kendi ülkesindeki işci sınıfına bu paydan vererek kapitalist sisteme bağlamaktadır (Goldstein\&Pevehouse, 2013, ss.507). Gandhi'e göre ise bitmek bilmeyen bir ticari yayllma sistemi olarak koloni ve potansiyel tüketiciler arayışı olduğunu söyler (Childs\&Williams, 1997, s.33). Hegemonya terim olarak özünde "bir devletin ya da süper devletlerin başka ülke ya da bölge üzerinde liderlik, denetim, etki gibi esas belirleyi-

1 "Emperyalizm”, Osmanlıca-Türkçe Ansiklopedik Büyük Lügat, İstanbul:Türdav, 1993, s.233. Ayrıca, "Bu maksat için çok defa silahlı harp, hem masraflı hem de hürriyet fikriyle bağdaşmadığından zamanımınızda daha sinsi ve maskeli bir emperyalizm şekline başvurulmaktadır. Modern emperyalizm denilen bu şekli iktisadi ve kültür hayatı bakımından bir ülkeyi kendine bağlamak suretiyle menfaat sağlamaktadır. Gelişmiş ülkeler, az gelişmiş ülkeleri bu yolla kendilerine bağımlı hale getirmektedir. İnsanları kendi kültür ve ideolojileriyle yetiştirdikleri için felsefe, siyasi görüş ve yaşayış bakımından kendilerinden ayrılamaz hale getirmektedir."

2 “Emperyalizm”, Faruk Sönmezoğlu, Uluslararası İlişkiler Sözlüğü, Cem Yayınevi, 1992, s.122. Emperyalizmin nedenleri: ekonomik karlılık, burjuvazinin Pazar arayış1, kapitalizmin doğası, insan toplumu ya da devletlerin sosyal darwinizm yayılması, ülkelerin güvenlik ve stratejik ihtiyaçları: kaynaklar, güçler dengesi, etik ve ahlaki nedenlerle zoraki liberal demokrasi ihracı, az gelişmiş ülkelerin uluslararası yardım ve ticareti yeni sömürgecilik olarak görmesi şeklinde çok boyutlu özetlenmiştir. 
ci unsurların ikili etkileşim ve güç dağ 1 lımında simetrik olmayan bir niteliksel görünümü vardır (Sönmezoğlu, 1992, s. 151). Bu iki kavram aynı anlamda da kullanılmaktadır.

Jhon A.Hobson, Emperyalizm kavramını ilk kullanan yazar olarak kapitalist toplumda tasarruf yapan sınıf aşırı üretim ve yetersiz iç tüketimden dolayı fazla kar elde etmek için ülke dışında Pazar ve yatırım arayışına girmeleri beraberinde emperyalizmi getirmektedir. Hobson'a göre XIX. Yüzyıl Avrupa'sında emperyalizmi ekonomik nedenler değil askeri, politik, dini ve psikolojik nedenler sebep olmuştur. Çünkü finans kapitalizmin, emperyalizm ve savaşı kendi menfaatleri için istediğini, emperyalizmi yok etmek için kapitalizmin yok edilmesini savunur (Hobson, 1999, ss.365-368).

Schumpeter, Lenin ve Hobson'dan farklı olarak emperyalizmin sadece ekonomik sebeplerle açıklanmasına karşı çıkar. Çünkü devletler tarihsel olarak genişleme, güvenlik, yönetmek ve kazanmak arzusuyla atavist toplumların, savaş makinesi, saldırganlık ve tekelci kapitalizm dış politika aracı olarak emperyalizm politikası izlemektedir (Ar1, 2008, ss.308-310).

Morgenthau, emperyalizmi devletler arasındaki güç ilişkilerinde çoklu ya da ikili kurulu güçler dengesini yani statükoyu revize eden diş politikalar şeklinde açılar. Bu yönüyle bir devletin güçlenmek istemesi doğaldır, örneğin ABD, Çin ve İngiltere'nin önceki imparatorluk düzenini ya da kurulu düzeni koruma mücadelelerini emperyalist faaliyet olarak görmez (Arı, 2008, ss.303304).

Galtung, emperyalizmin bir sistem olarak dünyada çıkarları uyuşan ve çakışan bağlamında çevre ve merkez ulusları ayırarak, her ikisine de merkezçevre metropol ekleyerek bunlar arasındaki ilişkilerin dikey ve feodal çerçevede eşitsiz ve sömürüye sebep olduğunu, merkez ve çevre ülkenin merkezleri arasındaki çıkar uyumunun hegemonik bir ilişki olduğunu belirtir. Ayrıca emperyalizmi ekonomik, siyasi, askeri, iletişimsel ve kültürel olmak üzere sinıflandırarak amatör emperyalizmin salt zorba şiddet kullanacağını oysa profesyonel emperyalizmin yapısal olarak güce başvurduğunu söyler (Galtung, 1996, ss.265-273).

Wallerstein, dünya sistemi modeline göre kapitalist ekonomi dünya ekonomisini küresel ölçekte şekillendiren, sermaye birikiminin kapitalist üretim teknolojisinin dinamizmine bağlı olarak değişen kapitalizm ekonomik yapısıyla dünya ekonomisinin parçası devletler merkez ve çevre arasında yarı çevrenin daha az kazanç ve gelişimden yararlanmasıdır. Bu dünya sisteminde hegemonik güçlerin hakimiyeti(askeri, siyasi, ekonomik üretkenlik, ideolojik yetenek ve liderlik) bu dünya imparatorluğu da olabilir, fakat kapitalist ekonominin doğasından dolayı sürekli değildir (Wallerstein, 2004, ss.130-137). 
Klasik realist teoriler anarşik sistemde devletlerin emperyalist yayılma politikalarını güvenliğini garantiye almak adına onaylaması gibi coğrafyayı ön plana alan jeopolitik hakimiyeti savunan teoriler de bu tür yayılmacı politikalara yardımcı olması, örneğin, İngiliz, Napolyon, Hitler'in Emperyalizmi ve Savaş sonrası süreçte Amerika'nın üstünlüğünü sürdürmeye yönelik siyasi teoriler olarak görülmüştür (Ar1, 2006, s.227).

Hegemonya kavramı Gramsci'ci anlamda öteki devletlerin rızasını alacak şekilde bir uzlaşı sonucu hâkimiyet kurulmasını içerir ve gerektirirken, imparatorluk siyaseti öteki devletler üzerinde onların rızasına bakmaksızın bir tahakküm ilişkisini ifade eder. Diğer bir ifadeyle İmparatorluk kaba gücün kullanımına vurgu yapar iken Gramsci' anlamda hegemonya Nye'ın da ifade ettiği gibi yumuşak gücün önemine vurgu yapmaktadır. İmparatorluk, Roma, İngiltere, Fransa, Rusya, Osmanlı gibi kuruluşundan itibaren sürekli yayılma içinde bulunan ABD'ye atfedilen bir özellik iken, hegemonya, İkinci Dünya Savası sonrası süreçte Amerikan liderliğinde kurulan ve Soğuk Savaş sonrasında da Washington tarafından yeniden şekillendirilmeye çalışılan dünya düzenini ifade etmek için kullanılmaktadır. Yıldızoglu ise bu durumu şu şekilde ifade etmektedir (Yıldızoglu. 2003),

"imparatorluk için esas ve belirleyici olan askeri güç iken, hegemonyacı için esas olan uluslararası alanda belli birtakım işlevleri yerine getirerek, bir anlamda "kamusal hizmetler" sunmaya devam ederek, "herkesin" ve "sistemin" uzun dönemli çıkarlarını koruyarak liderliğini kabul ettirebilmesidir."

Emperyalizm genelde kendini daha kapsamlı üst bir söylemle retoriksel olarak hem ulusun iyiliğini hem de insanlığın iyiliğini düşünen hegemoniksahiplenici bir yol izler (Fouskas\&Gökay, 2008, s.134).

Hegemon güce sahip bir devlet bizzat oluşturulmasında rol oynadığı uluslararası norm ve kurallara riayet ederler ve diğer devletlerin de bu sistemi meşru kabul etmeleri için evrensel bir dil oluştururlar. Dolayısıyla oluşumunda bizzat rol oynadığ 1 bu sisteme riayet etmeyen hegemon güçler meşruiyetlerini kaybederler. Hegemonik güç düzeninde, zayıf devletlerin "Bandwagoning" olarak kavramsallaştırılan siyaseti izleyerek belirli bir hegemonik güç ile kuracağı ilişkiden kar edebilmesi ve onu model alıp taklit edilmesi söz konusu iken, herhangi bir kuralla kendini bağlı hissetmeyen ya da kendisini düzenin kurallarının üzerinde gören imparatorluklar, karşı konulmaz bir askeri güçle 
tamamen rakiplerin etkisizleştirilmesine ya da bertaraf edilmesine dayalıdırlar (Arıboğan, 2004, s. 50).

İmparatorluklar, rakiplerini ortadan kaldırıp mülklerine el koydukları halde, kapitalist hegemonlar rakiplerine öncülük eder ve dolayısıyla, onlara er geç hegemona "yetişme" imkânı verirler (Özel, 2003, ss.12-19). Bu da hegemonun oluşmasına katkı verdiği bir uluslararası siyasi düzen içinde gerçekleşir. İmparatorluk için esas olan uluslararası sorunların çözümünde tek başına ve hızla davranabilmek iken, hegemonyacı güç açısından verili ittifaklar sistemini korumaya çalışarak hareket etmek esastır (Yıldızoglu, 2003, s:344). Hegemon güce bu niteliği kazandıransa kendi kendisini uluslararası kurumsal yapılanmalar yoluyla sınırlayabilme yetisidir. Ayrıca, hegemonyanın süresi, karşı hegemonik güçlerin ortaya çıkışına kadarken, imparatorluklar yüzyıllar boyu kurdukları hâkimiyeti sürdürebilmektedirler (Kurtbağ, 2007, s. 447).

Emperyalizm klasik merkantilist kolonicilik anlayışından farklıdır. Koloniciliğin özünde değerli madenler, hammadde, serbest ticaret, liman ziyareti ve yerli halkın gelenek ve siyasi yapılarına müdahale olmazdı ve ekonomik faaliyetler gerçekleşirdi, oysa ikinci sanayileşme ile birlikte daha çok gıda, endüstri hammaddesi talebini yerli tüccarların sağlayamaması ve Pazar arayışı kolonicileri bu bölgelere sermaye ihracı yaparak doğrudan plantasyonlar, yerleşimciler, fabrikalar, madenler, limanlar, rafineri, posta, yollar, bankalar, oteller gibi yatırımlar yapılmış ve borçlar verilmiştir. Fakat liberal serbest ticaret ve ekonomik bağımlılık 1870'lerde muhafazakar milliyetçilik çerçevesinde hızlı sanayileşmenin sorunları, talep ve 1929 Ekonomik krizle birlikte vatansever şoven milliyetçiliği 'İmparatorluk' kavramının prestij, büyüklük ve görev bağlamında bu yatırımlar beraberinde askeri, siyasi, mali müdahale ve öteki yeni emperyalist güçler arasında rekabeti ve çatışmayı da getirmiştir (Kunetsen, 1992, ss.171-172). Burada amacimız emperyalizmi liberal serbest piyasanın doğal gelişimi şeklinde göstermek değil onun siyasi, ekonomik, hukuki, sosyal ve kültürel asimilasyonist, müdahaleci, "oriental" hakimiyeti, post-colonial sömürü miras yapılarını anlamamızı sağlayan zengin içerikli bir disiplin oluşturmuştur (Ashcroft vd, 2002).

Emperyalizm, süreç olarak bir devletin gücünün ve otoritesinin toprak elde ederek başka milletler üzerinde siyasi ve ekonomik hakimiyet ve kontrol sağlamaktır; Avrupa devletleri, okyanus ve kıtaları aşarak Amerika, Avustralya, Yeni Zelanda, Afrika, Asya ve Ortadoğu'da küresel ölçekte bağll, birleşik, sürekli ilk Avrupa emperyal sistemini kurdular (Opello\&Rosov, 2004, s.167). $\mathrm{Bu}$ Avrupa emperyal sistemi gittiği bölgelerde sadece kişi, millet ve kurumları etkilemedi aynı zamanda onların rutin sosyal yaşamlarını ekonomik(özel mülk, kapitalizm), siyasi (ülkesel ulus devlet, askeri baskı altına alma), kültürel (hristiyanlık, humanizm) alanlarda hegemon Avrupa toplumunun nüfuzuna 
girdi (Opello\&Rosov, 2004, s.175). 19.cu yüzyıldan II. Dünya Savaşının sonuna kadar doğuya hakim olan emperyal İngiltere ve Fransa'dan sonra ABD de savaştan bu yana günümüze kadar bölgede hakim bir güç olarak önceki Orientalist güçler gibi davranmaktadır (Said, 1991, s.18). Petrol gibi enerji kaynaklarının 2/3'nü sağlayan Ortadoğu küresel jeopolitik güçler dengesinde önemli bir yere sahiptir. 1975-85 aras1 yıllarında petrol talebini \%4.5 üretim artırmak için 2.2 Trilyon \$ ekstra sondaj yatırımına ihtiyaç varken; dolayısıyla uluslararası sistemde petrol gibi kaynakların arzı kontrol ve denetim için antlaşma sağlanması sadece enerjide güvenlik değil aynı zamanda yeni bir sorumluğun gelişimiyle dünya devletinin önü açılmış olacaktır (Sampson, 1976, ss.320-321). SSCB'nin 1990'larda çöküşüyle ABD'nin tek süper güç kalmas1, Thatcher ve Reagan'ın şekillendirdiği Neoliberal ajanda tüm Avrupa'daki devletlere, Rusya'ya, Latin Amerika, Asya ve Afrika'daki devletlere de uygulandı; böylece küresel düzende ABD hegemon "hipergüç" olarak ve Neoliberal ideoloji baskın hale geldi (Opello\&Rosov, 2004, s.1). Bu yönüyle Neo-liberal kozmopolitanlar ABD'nin öncülüğünde Soğuk Savaş sonrası süreçte küresel yönetişim ve uluslararası örgütler aracılığıyla "Pasifik Birliğì" kurularak siyasi ve ekonomi alanlarında uluslararası topluluk devletlerin egemenliğini sinırlandırabilir (Gowan, 2001, ss.79-93). Örneğin, İngiltere'de Thatcherizmyeni sağ bağlamında uygulanan birikim ve hegemonik projeler(Pasif devrim ya da Yayılmacı hegemonya) iki uluslu hegemonya(finans kapital-emekçiler) ekonomik olmasa da siyaseten başarılı olmuştur. Oysa Türkiye'de bu süreç kısmen zora(1980 askeri müdahale) özünde bir güçlü hegemonik proje ve ideoloji olmadan, reaksiyoner ya da ilerici gruplar çıkması için yapılmıştır. Ekonomik ve sosyal dinamikler arasındaki yapısal farklılık olması ve oydaşma arayışının olmaması ve baskıya rağmen bunların etkisi artmış, fakat siyasette yayılmacı hegemonya, devleti organik ideolojili geliştirerek milliyetçi muhafazakar dinamiklerin güçlendirilmesini bölgedeki yeni güçler dengesinin oluşturulmasına(Pakistan, Iran, Türkiye) bağlayabiliriz (Kaya, 2002, ss.4-8).

Küreselleşmeyle birlikte kapitalizmin global ulus-üstü örgütleriyle yayılması ulus devletin siyasi, kültürel, etnik bölünmeler; çalışanların iş ve sosyal haklarını, işsizlik ve göç gibi konularda güvensizlik ve tehdit oluşturmaktadır (Piven, 2006, ss.278-285). Aynı şekilde, dünya ülkeleri sadece askeri teknoloji sahasında değil siyasi, ekonomik, sosyal ve kültürel olarak da Batılılaşma sürecine maruz kalmışlardır (Harrison, 1991,ss.39-57).

\section{Eylül Sonrası Irak Savaşı ve Hegemonya-İmparatorluk Yaklaşımları}

Amerika'nın Ortadoğu politikasının temel amaçları, Bölgeden serbest şekilde petrol sevkiyatının yapılması, dost ve müttefik rejimlere silah ihracatı ve 
güvenliğinin sağlanması, İsrail' in korunmas1, rakip jeopolitik güçlerin(SSCB, $\mathrm{AB}$, Rusya, Çin) dışlanması gibi politikaların yanında serbest ticaret, insan hakları, demokrasi ve terörizmin önlenmesini ve kitle imha silahlarının önlenmesini amaçlayan politikalar izlemektedir (Edwards, 2011, ss.260-267).

Genelde emperyalizm antiemperyalist politikalara neden olur, dolayısıyla farklı dönemlerde farklı ideolojiler antiemperyalist politikalar izlemiştir. Batının savaş sonrası süreçte Müslüman coğrafyaya müdahale etmemesi, doğal kaynakların kontrolü, batılı askeri üslerin kaldırılması ve Filistinlilerin adil bir barışa kavuşmasını isteyen solcu Arap milliyetçi rejimlere karşı radikal İslami grupları desteklemiştir. ABD, kendisine yakın yönetimleri görevde tutabilmek için dünyanın çeşitli yerlerinde düşmanca davranan yönetimleri gizli ya da doğrudan askeri operasyonlarla devirmekten ve farklı muhalif gruplarla işbirliği yapmaktan tereddüt göstermemiştir (Fuller, 2013, ss.282-283): Kore (1950-53), İran (1953), Guatemala (1954), KostaRika (1955), Suriye (1957), Endonezya (1958), Dominik (1960), Peru (1960), Ekvador (1960), Kongo (1960), Vietnam (1961-1973), Küba (1961), Brezilya (1964), Şili (1972), Angola (1975), Nikaragua (1981), Lübnan (1982-84), Granada (1983), Panama (1989), IrakKuveyt (1991), Somali (1993), Bosna (1994-95), Kosova (1999), Afganistan (2001-devam), Irak (2003-devam), Libya (2011), Suriye (2014---).

Organski, hegemon güce eşit olmadan, kurulu uluslararası düzeni-statükoyu değiştirmenin akıllıca bir davranış olmadığını(I. ve II.ci dünya savaşlarında Almanya, İtalya ve Japonya örneği); Şayet hakim güç rakip güçlerin eşit güç seviyesine gelmeden ya da güçler dengesini bozmadan müdahalesini ise "önleyici savaş/preventive war" olarak açıklamaktadır (Organski, 1996, s.306).

Özellikle 11 Eylül olaylarından sonra yayınlanan birçok çalışmada ABD'yi bir imparatorluk yani neo-emperyalist olarak tanımlandırma veya onu geçmişteki imparatorluklarla kıyaslama eğilimleri, hatta sektör haline geldiğini savunan karşıt görüşler de vardır. ABD'nin bir emperyalist olarak tanımlanması geçmişte daha çok Marksist görüşler çerçevesinde ortaya çıkmış olmasına rağmen 11 Eylül'den sonra Bush Yönetimi'ne muhalif olan liberal kesimde de bu eğilimin artış gösterdiği görülmektedir. Bunun üç nedeni olduğu söylenebilir. İlk olarak, yeni muhafazakâr çevrenin Amerikan karar vericileri üzerindeki etkinliğidir. İkinci olarak ise yeni muhafazakâr çevrenin görüşlerinin somutlaştı̆̆ 1 bir belge olan Bush Yönetimi'nin Ulusal Güvenlik Stratejisi (UGS)'dir. Bush Doktrini olarak adlandırılan UGS' de ortaya konan yaklaşımların Afganistan'ın ve Irak'ın işgaliyle somutlaştırılmış olması, uluslararası ilişkileri teorik ve pratik yönden değiştirmek istemesi, Soğuk Savaş döneminde "caydırma ve çevreleme siyasetinin" ulusötesi teröristler ile kitle imha silahlarını kapsayan yeni yüzyılın tehditlerinin üstesinden gelmede yetersiz kalan klasik savunma yöntemlerini aşarak uluslararası hukukta sorunlu olan "preemptive war" önalıc1- 
sezgisel meşru müdafaa doktrinini öngörmesidir (Taşdemir, 2006, s.238). Bu nedenle, 2001'den sonra pek çok çalışmada ABD'nin stratejilerini veya konumunu değerlendiren yazarlar ABD'den genel görünümünü imparatorluk ya da yeni emperyalist olarak adlandırmayı tercih etmişlerdir. ABD, küreselleşme ve kalkınma çerçevesinde başlayan yeni emperyalizm politikalarına uluslararası komünizmle olduğu gibi El-kaide gibi uluslararası terörizm, Haydut devletler, Şer Ekseni, Afganistan ve Irak İşgalleriyle askeri tek taraflı ve önleyici müdahale politikalarıyla 11 Eylül sonrası süreçte Emperyal projesini uygulamaktadir (Petras\&Veltmeyeri, 2006, ss.323-324).

$\mathrm{Bu}$ konuda elbette farklı görüşler de ifade edilmiştir. Gerek realist politikalar ve liberal uluslararasıcılık eleştirilmiştir. Realizmin caydırıcılık bağlamında aktörlerin fayda-maliyet rasyonel tercihini yapması, terörist güçlerin Kitle İmha Silahlarına ulaşması, önleyici ve tek taraflı saldırılar hem teröristler ve Saddam için doğru değildir. Amerika'nın Dünya Savaşları ve Soğuk Savaş döneminde Avrasya kıtasında düşman güçler dengesini engellemek için angaje olmuştur. Bush ve Clinton, Somali, Bosna ve Kosova'da ulusal çıkar gözetmeden ve gönülsüzce BM onaysız insani müdahalede bulundu (Lieber, 2005, s.32). Liberaller, işbirliği, çok taraflılık, diplomasi, uluslararası örgütlerin, uluslararası sorunların küresel yönetişimle halledilmesi: KYOTO, Uluslararası Ceza Mahkemesi, Kara Mayınlarının Yasaklanması antlaşmalarının imzalanması ve BM desteğini ararken ABD'nin tek taraflı, önleyici müdahale, kuvvet kullanma ve üstünlük kurma stratejilerine karşı çıkarlar (Ikenberry, 2004, ss.262-282). Oysa, bu uluslararası örgütler demokratik anlamda etkin verimli değiller, BM veto sistemi, uluslararası toplumun hızlı sorumluluk ve karar alma sorunu, akıllı gücün kültür, değer ve sivil toplum ölçeğinde muğlak kalması, Arab-İslam medeniyetinde demokratik değerleri cihatçıların dışlaması gibi önemli açmazlar vardır (Lieber, 2005, s.32-37).

11 Eylül sonrasında, terörist faaliyetlerde bulunan küçük aktörlerin büyük devletlere ağır kayıplar verdirmesi anlamına gelen ve literatürde asimetrik tehdit olarak ifade edilen tehlikelere karşı koyabilmek için $\mathrm{ABD}$ güvenlik politikalarında köklü değişiklikler yapılmıştır. Bu çerçevede gerçekleştirilen adımlardan ilki, Bush'un, 29 Ocak 2002'de yapmış olduğu “Birliğin Durumu Konuşması" olmuştur. Bu konuşmada Bush, İran ve Irak Kuzey Kore ülkelerini şer ekseni ülkeleri şeklinde adlandırarak bunların kitle imha silahı üretme yünündeki çabalarının engellenmesi gereğine vurgu yapmıştır (Johnson, 2005, ss. 253-254). Bush bu ülkeler hakkında

"Bu konuda düşünüp taşınacă̆ız elbette. Ama zaman bizim lehimizde değil. Tehlikeler ortaya çıkarken ben olayların olmasını bekleme- 
yeceğim. Tehlike yakınlaşırken ben durup beklemeyeceğim. Amerika, dünyanın en tehlikeli rejimlerinin kendisini dünyanın en yıkıcı silahlarlyla tehdit etmelerine müsaade etmeyecektir.

sözleriyle Amerikan halkının dikkatini bu şer ekseninin yarattı̆g 1 tehdide çekmeye çalışmıştır. Burada ABD yönetimi, geçmiş dönemlerdeki çevreleme ve caydırıcılık vazgeçerek daha önce haydut rejimler olarak adlandırılan bu ülkelere karsı "önalıcı" müdahalede bulunma hakkına sahip olduğunu ileri sürmekte, ama aynı zamanda KİS geliştirmek suretiyle bu kategoriye girebilecek, potansiyel ülkelere karşı da aynı şekilde hareket edebileceğinin mesajını vermiştir. Bu şekilde, ABD yönetimi, el-Kaide ve Afganistan meselelerin çok ötesine geçerek çok daha kapsamlı (11 Eylül sonrasında dünyanın yeniden şekillendirilmesi) projesini hayata geçirmeye başlamıştı. Aslında Irak müdahalesinin temelleri Bush'un bu konuşmasında atılmıştır diyebiliriz.

Nitekim, 1 Haziran 2002'de West Point'te yaptığı konuşmasında, Baskan Bush, düşmanı harekete geçmeden önce etkisiz hâle getirmeyi ve bunun ABD'nin evrensel hakkı olduğunu öngören önalıcı askeri müdahale doktrinini (preemptive strike) ilan etti. Bush bunu

“terörizme karşı savaşın savunmayla kazanılamayacağını” söyleyerek, "Düşmanla savaşa girişmeli, onun planlarını imha etmeli ve tehditler daha doğmadan onları boğmalıyı. İçine girmiş bulunduğumuz dünyada biricik güvenlik yolu, eyleme geçme yoludur",

diyerek ortaya koymuştu ("Irak'ta Savaşa Hayır", 2014)3. "Bush Doktrini”" olarak adlandırılan bu yaklaşım, 11 Eylül öncesi yönetimin geleneksel yaşamsal çıkarların savunulması ile sınırlandırdığı askeri güç kullanımını, bu doktrinle birlikte dış politikanın temel unsuru haline getirmiş bulunmaktaydı.

Bush'un bu söylemlerinde düşman ise tanımsız bırakılmış ve ABD bu sayede kendisine arzu ettiği hedefe karşı askeri güç kullanmak için bir hareket alanı oluşturmak istemişti. Dolayısıyla, tehdidin ve düşmanın tanımını kendi belirleme serbestisi içinde Bush Doktrini, önce saldıran taraf olma vasıtasıyla en üstün taraf olmayı arzulayan bir strateji izlemekteydi. Diğer bir ifadeyle, $\mathrm{ABD}$, terörle savaş söyleminin de ötesine geçerek iyi huylu-rızaya dayalı he-

3 http://www.savaskarsitlari.org/arsiv.asp?ArsivTipID=9\&ArsivAnaID=11634 erişim 17.06. 2014 
gemonya yerine mutlak-askeri üstünlüğe ve kaba güç kullanımına dayalı bir anlayışı benimsediğini söyleyebiliriz.

Son olarak Bush Doktrini olarak nitelendirilen yukarıdaki bahsetmiş olduğumuz düşüncelerin Afganistan'ın ve Irak'ın işgaliyle hayata geçirilmesi ABD'nin bir neo-emperyalist olduğu düşüncesinin yaygınlaşmasına büyük ölçüde katkıda bulunmuştur. Bu nedenle, 2001'den sonra pek çok çalışma ABD'nin stratejilerini veya konumunu değerlendirirken imparatorluk ya da yeni emperyalist olarak adlandırmıştır. Afganistan sonrasında Irak işgali açıkça kurucu uluslararası antlaşmalara aykırı olarak ABD'nin İmparatorluk projesine uygun olarak önleyici vuruş çerçevesinde devletlere son verme, rejim değişikliği ve doğal kaynaklara müdahale bağlamında yeni sömürgecilik politikası uygulanmaktadır (Özcan, 2003, s.271).

Soğuk Savaş sonrasında, ABD'nin hegemonyasına karşı bir başka hegemon güç olacak olan devlet mekanizmasının yerini, 11 Eylül' sonrası terörist örgütler ve bu örgütlere destek veren rejimler almıştır. ABD bu gruplara ve bu guruplara destek olan rejimlere karşı girişeceği faaliyetlerini önleyici saldırı (preventive attack) temeline oturtmuştur. Bu faaliyetlerin tüm dünyanın güvenliğini sağlamak, terörizme ve aşırılığa karşı Afganistan ve Irak'a demokrasi getirmek için yapıldığını ifade ederek ABD bu girişimleri uluslararası kamuoyunun rızasının kazanılması hususunda meşrulaştırmak istemiştir. Fakat hem 11 Eylül akabinde gerçekleşen Afganistan'ın işgalinin, hem de Mart 2003 'te başlayan Irak'ın işgalinin, ekonomik, toplumsal ve siyasi sonuçları neticesinde, bu işgallerin ABD'nin mevcut hegemonyasını küreselleştirmeye ve pekiştirmeye yönelik stratejinin adımları olduğu yönünde literatürde ciddi görüşler oluşmuştur (Johnson, 2005, 253-254). Fakat işgalin olumsuz sonuçları Amerika'yı hayal kırıklığına uğratmıştır (Gause, 2009, ss.285-286). Irak'ın işgal sürecinde Şiiler, Sünnilerden daha çok direnç göstermiş, Baas rejimi yıkıldıktan sonra ise Bagdat'ta 6 hafta içinde hiç Amerikan askeri ölmemişti; Ne zaman ki ordu dağıtıldı ve sonrasında BM Konseyi İşgalcileri Yönetim Konseyi olarak tanımasıyla 19 Ağustos'ta BM temsilcisi ve merkezini 19 kişiyi intihar saldırısıyla Bagdat ve Musul'da Baas ve Sünniler direniş ve ayaklanma başlattılar (Pelham, 2008, ss.117-118).

Soğuk savaş sonrasında yeni diplomasi anlayışı konusunda, ABD'nin herhangi bir BM kararı olmadan gerçekleştirdiği Irak müdahalesi bir dönüm noktası niteliğindedir. Mevcut uluslararası sistem ve uluslararası hukuk kurallarına aykırı şekilde sistemde tek hâkim hegemonik güç olarak hareket eden ABD, tüm dünyanın tepkisini çekmiş ve Birleşmiş Milletler Güvenlik Konseyi'nin önüne silah denetimini sağlayacak önlemler yerine, bu denetimleri büsbütün olanaksız hale getirerek, silahlı güç kullanımı seçeneğine başvurmuştur. ABD'nin karşısında kıta Avrupa'sını temsil eden Almanya ve Fransa'nın mu- 
halefeti bile, ABD'yi kararından döndürmemiş, müdahale ayrıca Avrupa Birliği ülkelerinin kendi içinde bölünmesine ve oluşturulmaya çalışılan ortak dış politikanın zarar görmesine yol açmıştır.

Irak'1 işgaline giden sürecin ilk ipuçlarını 2002 Eylül'ünde deklare edilmiş olan "Yeni Ulusal Güvenlik Stratejisi"nde bulabilmek mümkündür. ABD söz konusu stratejide, Irak'ın kitle imha ve biyolojik silahlara sahip olduğunu, bundan dolayı dünya barışına karşı potansiyel bir tehdit oluşturduğunu ifade etmiş ve ABD'nin tehdit unsurlarını bertaraf etmek, dünya barışını sağlamak ve hem kendisine hem de müttefik karşı gerçekleştirilecek terörist saldırıları engelleyebilmek için önleyici tedbirlere başvurabileceği açılanmıştır. ABD'nin Irak'la başlayan Ortadoğu'ya yönelik politikalarında klasik pozisyonundan radikal değişiklikler yaparak geleneksel petrol zengini, feodal, otoriter rejimlerden desteğini çekerek bölgede jeopolitik kaymalara, demokratik devrim-reform hareketlerini destekler görünmektedir (Özdağ, 2003, s.150). Irak coğrafi olarak bölgenin Iran, Irak, Türkiye, Suudi Arabistan ve diğer ülkelerin yanında ABD-İsrail için doğal kayakların yanda dini, mezhepsel, etnik gibi her türlü panc1-hareketlerin jeo-politik fay hatlarını da denetlemektedir (Ünal, 2003, s.309.).

11 Eylül 2001 tarihinde düzenlenen saldırılar Amerikan dış politikasında radikal değişiklikler yapılmasına sebep olmuştur. Bush yönetiminin 11 Eylül 2001 sonrasında terörle mücadeleye karşı oluşturduğu Bush doktrini olarak ifade edilen stratejinin, en tartışmalı hususlarından birisi, "önleyici müdahale" kavramı olmuştur. "Önleyici müdahale" stratejisinin Irak'a müdahaleyi meşru ve politik bir çerçeveye oturtarak haklı göstermenin gerekçesini oluşturmaya hizmet ettiğine yönelik literatürde muhtelif görüşler yer almıştır. Söz konusu kavramın teröristlere ve kitle imha silahlarına sahip olmak isteyen haydut devletlere karşı gerekli olduğunu savunanların yanı sıra, müttefiklerinin ABD'ye olan şüphelerini ve güvensizliğini artırabileceğini, ABD'nin dünyadaki meşruluğunu olumsuz etkileyeceğini; ABD'nin özellikle küresel rakipleri Rusya ve Çin'in kendi önleyici müdahalelerinde bulunmaları konusunda bu ülkelere imkan tanınacağını düşünenler de olmuştur. Bush Doktrini ile birlikte ilk defa haydut devlet tanımı yapılmıştır. Bu tanıma göre haydut devletler, "kendi halklarina merhametsizce davranan", "uluslararası hukuka saygisı olmadiğını gösteren, komşularını tehdit eden, ve katı bir şekilde tarafi oldukları uluslararası antlaşmaları ihlal eden", "kitle imha silahların elde etme azminde olan", "dünya çevresinde terörizmi destekleyen" ve "temel insani değerleri reddeden ve ABD'den nefret eden" devletler olarak ifade edilmiştir (Tunç, 2009, ss. 1-16).

ABD'nin Irak'in petrol kaynakları üzerinde hâkimiyet kurarak hegemonyanın maddi altyapısını sürdürme ve güçlendirme isteği işgalin en belirleyici 
sebeplerinden biri olduğu yönündeki görüşler literatürde sıkça yer almıştır. ABD'nin Ortadoğu petrolüne olan bağımlılı̆̆ dikkate alındığında, ABD'nin Irak petrol kaynakları üzerindeki kontrolü ve bu kaynakların güvenliği ABD için hayati önem taşımaktadır (Johnson, 2005, ss. 253-254). Chevron ve Halliburton gibi Amerikan petrol şirketlerinin savaş süresince ciddi kazançlar sağlaması, ABD güçlerinin Irak'a girişi ile birlikte müzelerin ve milli arşivlerin zarar verilmesine seyirci kalırken, Petrol Bakanlığı'nı koruma altına alması ve Avrupalı petrol şirketlerinin Irak hükümeti ile yapmış olduğu anlaşmaların $\mathrm{ABD}$ yönetimi tarafindan iptal edilmesi bu durumun en önemli göstergelerindendir (Kurtbağ, 2010, s:332). Aslında 11 Eylül akabinde sadece Irak'ın işgalinde değil, Afganistan'ın işgalinde ve genel olarak Afrika'ya ve Ortadoğu'ya yönelik ABD ilgisinin ve müdahalesinin artmasında da enerji kaynaklarına erişim sağlamak isteyen hegemonyanın maddi kapasitesini artırmak ve karşı hegemonyanın oluşmasını engellemek başlıca nedenler arasındaydı.

Meşru savunma hakkı uluslararası hukukun devletlerin kendi güvenliklerini kuvvet kullanma yolu ile garanti altına aldıkları haklar, esas itibariyle Milletler Cemiyeti(1919), ParisPaktı: Kellog-Briand ve BM Sözleşmesiyle sadece savaşı değil, devletin toprak bütünlügü ve siyasi bağımsızlığına ve BM'nin hedef ve amaçlarıyla örtüşmeyen her türlü kuvvet kullanımını yasakladıktan sonra uluslararası barış ve güvenliği "Ortak Güvenlik" çerçevesinde mağdur ülkenin kendisini bireysel ve kolektif savunma hakkıdır (Aral, 1999, ss.1-5). BM Sözleşmesinin 51. Fıkrası ${ }^{4}$ bir devletin meşru savunma hakkını silahlı saldırıya uğradığında kullanır. Meşru savunmanın temel şartları: fiili bir silahlı saldırının olması, saldırıyı bir devletin silahlı gücünün yapması, meşru savunma için Güvenlik Konseyi kararı gerekli mi? Karar alındıktan sonra bu hak nasıl kullanılır soruları akla gelmektedir. İlk seçenekte fiili saldırı yok ise bu önleyici(preventive war:1967 israil-Mısır ve 1982 Osirak Saldırıs1) savaş olur ki bu konuda uluslararası hukukta çoğu yazar fiili saldırı dışında meşru savunma için kuvvet kullanmayı desteklemez. İkincisi için bir ülkenin egemenliğine, toprak bütünlüğüne, siyasi bağımsızlığına, BM hükümlerine aykırı şekilde silahlı kuvvet kullanımıdır. Burada BM Güvenlik Konseyi’nin görüşü saklı kalmak üzere, silahlı saldırıyı yapanın devlet olması ve yeter-

4 Mehmet Hasgüler ve Mehmet B. Uludağ, Devletlerarası ve Hükümetler Dışı: Uluslararası Örgütler, Alfa Yayınları,2010, , ss.555-556. Ek.3 Birleşmiş Milletler Şartı. 51.madde: "Bu Antlaşma'nın hiçbir hükmü, BM üyelerinden birinin silahlı bir saldırıya hedef olması halinde, Güvenlik Konseyi uluslararası barış ve güvenliğin korunması için gerekli önlemleri alıncaya dek, bu üyenin doğal olan bireysel ya da kolektif meşru savunma hakkına halel getirmez. Üyelerin bu meşru savunma hakkını kullanırken aldıkları önlemler hemen Güvenlik Konseyi'ne bildirilir ve Konsey'in İşbu antlaşma gereğince uluslararası barış ve güvenliğin korunması ya da yeniden kurulması için gerekli göreceği biçimde her an hareket etme yetki ve görevini hiçbir biçimde etkilemez." 
li yoğunlukta olmas1 gerekmektedir (Pazarc1, 2010, ss.521-522). 11 Eylül Saldırıs1 sonrası BM Konseyi 1373(2001) say1lı kararı, ABD'nin bireysel ve kolektif meşru müdafaa hakkını onaylamış ve üye devletlerin terörle her türlü mücadeleyi(dolaylı-dolaysız) önlemek için Konsey Komite kurmuş, fakat ABD Çin ve Rusya gibi devletlere emsal olmaması için sadece meşru savunma hakkını, Güvenlik Konsey'inden izin almadan Afganistan'a müdahale etmiştir (Taşdemir, 2006, ss.159-160).

ABD'nin Irak işgalinin meşru müdafaa kapsamında değerlendirilip değerlendirilemeyeceği işgal sonrasından bugüne tartışma konusu olmuştur. BM 51.ci madde ve Uluslararası hukuk kurallarına göre bir devlete karşı meşru savunma hakkına başvuran ülkenin, bir silahlı saldırıya uğramış olması veya böyle bir saldırının gerçekleşeceğinin kesin olması, gerçekleşen saldırıya karş1 savunma amaçlı eylemin aciliyet, gereklilik ve orantıl11lk meşru müdafaa eylemi dışında hiçbir yolun kalmamış olması konusunda bütün devletler mutabıktır (Taşdemir, 2006, ss.199). Ancak ABD’nin Irak işgali “öncelikli” (preemptive) meşru müdafaadan çok "tahmini/önleyici" (anticipatory/preventive) bir meşru müdafaa eylemidir. Tahmini/önleyici meşru müdafaa eylemi şu an tehdit oluşturmayan ama ilerde tehdit oluşturma "ihtimali" olan bir devlete karşı gerçekleştirilmektedir. Tahmine dayalı meşru müdafaanın hukuki kabul edilmesi, saldırganın, kurbanının gelecekte kendisine yönelik tehdit oluşturacağ 1 iddialarına dayanarak bir devlete karşı şiddete başvurmasını mümkün kılacaktır (Kramer vd.,, 2005, s. 59). Bu şekilde, tahmine dayalı bir meşru müdafaa eylemi, uluslararası toplumun desteğini almamaktadır (Yee, 2002, s. 292). Doktrinde "öncelikle önleyici-engelleyici/preventive ve önalıc1-önleyici vuruş preemtive strike" kavramları dönüşümlü olarak birbirlerinin yerine geçerek kullanılmaktadır. Fakat, "önleyici-engelleyici/preventive war" silahlı bir çatışmada "vukuu muhakkak" değil ama "vukuu muhtemel" potansiyel bir düşman tehditini yok etmeyi amaçlayan önleyici saldırı hukuka aykırı bulunmaktadır. Bu yönüyle BM sözleşmesine hiç atıfta bulunmayan örf ve adet haline getirilmek istenen önleyici vuruş dış politikada strateji haline gelerek önleyici savaşla arasında fark kalmayacak şekilde örtüşüyor görünmesi dünyayı tıpkı realist güvenlik ikilemi gibi potansiyel ve dinamik olarak daha güvensiz hale getirecektir (Taşdemir, 2006, ss.240-241).

Nihai olarak Bush öğretisi Irak savaşı doğrultusunda kuvvet kullanma ile ilgili uluslararası hukuk kurallarını yeniden formüle etme, yorumlama çabasına girmiştir. Kohen'e göre Bush öğretisi şu özellikleri ortaya koymaktadır:

1. Kuvvet kullanma dış politikanın bir aracı olarak kabul edilir.

2. Ağır ihlal durumlarında uluslararası hukuka riayete zorlama, per se (kendi başına), kuvvet kullanmak için bir neden değildir. 
3. ABD tarafindan kuvvet kullanılması, mutlaka uluslararası hukuka riayet şartına bağlı değildir.

4. Kuvvete başvurmadan önce askeri olmayan araçları tüketmek, arzu edilir olsa da, bir önkoşul değildir.

5. Çıkar ve başarı, kuvvete başvururken dikkate alınan temel unsurlardır.

6. Tek taraflı (yani BM onayı ya da diğer ülkelerden destek olmaksızın) kuvvet kullanma olasılı̆̆g dışlanmış değildir (Kohen, 2007,s.226).

ABD, Irak'ta kitle imha silahlarının varlığı ihtimaline dayanarak kuvvete başvurmuş ancak iddialarını ispatlayamamıştır. ABD ayrıca El-Kaide ile Irak arasında bir bağ olduğunu iddia etmiş ancak bu iddiasını da ispatlamak konusunda başarısız olmuştur.

ABD'nin 11 Eylül sonrası Irak ve Afganistan'da uluslararası kamuoyunun büyük ölçüde rızasını almadan gerçekleştirmiş olduğunu operasyonlar küresel güç olma yolunda ilerleyen bir takım ülkelerin ulusal ve bölgesel çıkarlarına bir risk oluşturması dolayısıyla bu ülkelerin ciddi tepkiler göstermesine sebep olmuştur. Şüphesiz bu ülkelerden en önemli iki tanesi Rusya ve Çin olmuştur. Her iki ülke Şangay İşbirliği Örgütü bünyesinde ABD’nin Afganistan operasyonu sonrası hem ulusal hem de bölgesel çıkarlarına tehdit oluşturduğu konusunda uzlaşmışlar ve ABD'nin bölgedeki varlığına son vermek amacıyla örgüt bünyesinde beraber hareket etmişlerdir. Örgütün şimdiye kadar yapılmış olan hemen hemen her zirvesinde "tek kutuplu dünya kabul edilemez", "dünya çok kutuplu bir görünüm arz etmektedir" vurguları yapılmaktadır. Dolay1siyla Rusya ve Çin'in önderliğinde ki bu örgüt ABD'nin 2000'li yıllar sonrasında ne "hegemonyasını" ne de "imparatorluk" olarak kavramsallaştırılacak bir durumu kabul etmemektedirler. Bu gelişmeleri destekler nitelikte örgüt bünyesinde bir takım kararlar da alınmıştır.

Örgütün 2005 yılında yapılan zirvesinde üye devletlerin liderleri; ABD’nin Şı̇Ö topraklarındaki (Orta Asya Ülkelerinden Tacikistan, Kırgızistan ve Özbekistan) askeri üslerinin boşaltması konusunda karara varmışlardır. 11 Eylül olaylarından sonra ABD'nin terörizme karşı başlatmış olduğu mücadeleye destek vermiş olan örgüt üyesi devletler vermiş oldukları bu desteklerini çekmişlerdir. Bölgede yaşanan renkli devrim süreçlerinde ABD'nin bu süreçteki politikaları Rusya ve Çin dışındaki kimi Orta Asya Cumhuriyetlerini de rahatsız etmiştir. Rusya Federasyonu'nun ve Çin Halk Cumhuriyeti'nin baskını hafifletmek ve terörizm konusunda $\mathrm{ABD}$ 'nin desteğini almak isteyen örgüt üyesi Özbekistan, Kırgizistan ve Tacikistan 2005 Astana Zirvesi'nden sonra söylem değiştirerek Rusya ve Çin tarafında yer almışlardır. Zirvede ABD üslerinin yer adlığı bu üç devletin topraklarının "Şangay İşbirliği Teşkilatı Toprakları" olarak nitelendirilmesi konusunda alınan karar bunu destekler nitelikte bir karar 
olmuştur. Zirvede böyle bir ifadenin yer almış olması örgüt bünyesinde bütünleşme ve birlik oluşturma hususundaki bilincin gittikçe yaygınlaştığına işaret etmektedir. Şangay İşbirliği Teşkilatı Toprakları söylemi; ABD’nin bölgedeki askeri üslerinin faaliyetlerini sınırlama maksadı ile kullanıldığ 1 değerlendirilmektedir (Akgür\&Çakıroğlu, 2008, s.3).

Aslında ABD'nin Irakta bu denli cüretkar bir müdahale gerçekleştirebilmiş olmasının sebebi, Soguk Savaş sonrası süreçte "Tarihin Sonu" gibi Amerikan'ın tek kutupluğununda(Amerikan Yüzyıl1) kendisine liberal demokratik değerlerin yayılmasında rol belirlemesi. İkincisi Yeni Post-modern sistemin dünyayı parçalı bir siyasi(Batı Avrupa) ve ekonomik(DTÖ) düzene dönüştürmesi. ABD'nin Doğu Avrupa, Kafkasya, Afrika ve Ortadoğu'da askeri ve siyasi müdahaleleri bu coğrafyada güç politikasının gelenekselleştiği bir süreçte bölgesel bir gücün-örgütün(Arap Birliği, İslam Kalkınma İşbirliği) yahut bölge ülkelerini hegemona karşı kenetleyecek bir kitlesel-organize alg1nın bulunmamış olmasını da gösterebiliriz (Robins, 2009, ss.291-293). Vermiş olduğumuz Şangay İşbirliği örneğinde ABD’nin Orta Asya'daki gücü küresel bir güç olmaya aday iki ülke olan Rusya ve Çin tarafindan örgüt vasıtasıyla kısıtlanmaktadır. Dolayısıyla günümüz dünyasında bölgesel örgütlenmelerin hegemonun gücünü sınırlandırabildiği bir süreci tecrübe etmekteyiz.

İlk Körfez Savaşından, sonra BM Tazminatlar Komisyonu'na 214 Milyar \$ başvuru olmuş ve ikinci müdahale ile ülkenin ekonomik siyasi altyap1S1 yık1lmış, Petrolden yıllık 10 milyar\$ kazanan ve bunun \%25 tazminatlara gittiği düşünülürse (Taşkun, 2004, s.517) Irak’ta kurulu Lübnan benzeri çok etnikli sekteryan dini temsili sistem düzenin kısa ve orta vadede istikrarlı bir ekonomik ve siyasi yapı kurması zor görünmektedir. 2003'te Neo-CON Bush Yönetimi Büyük Ortadoğu Projesi ile Irak’ta rejim değiştirerek İslam Dünyasına örnek bir demokratik yapı inşa edecekti, fakat Ürdün, Yemen, Suriye, Suudi Arabistan gibi ülkelerden Selefi Vahabizmin saldırısı ABD'nin Irak ve Körfez eksenli bölgesel Pax Americana düzenine tehdit oluşturmuştur (Robins, 2009, ss.293-297). ABD hegemonyasını serbest piyasa ekonomisi ve demokrasi ihracı ile Ortadoğu'daki siyasi ve toplumsal sistemleri değiştirmeyi amaçlamıştı (Hudson, 2009, s.327). Fakat ABD bu politikaları ile realist dış politika hedeflerini Wilson idealizmini uygulamaya koyduğunda başarıya ulaşamamaktadır; örneğin işgal sonrası Irak rejimin İran'a ve Suriye'ye yaklaşımı, Hamas'ın iktidara gelmesi gibi (Brumberg, 2009, ss.389-394). Amerika Irak'ı işgal kampanyasını demokratik, istikrarl, bir petrol ihraç eden ülke olarak Irak'1 tasarlanmıştı, ama ABD, Vietnam ve Afganistan sonrası üçüncü uzun savaşına girmiş oldu. 2010 itibariyle 4,400 kayıp asker, 1 trilyon \$ fazla masraf, Iran-Irak savaşından fazla ölüm (500 bin), her 1/6 Iraklı içerde ve dışarıda mülteci, Bagdat, Kerkük, Musul etnik-sekteryan çatışmaların, seçim- 
lerin ve istikrarsızlığın hüküm sürdüğü Irak'ta Obama döneminde ABD askerlerinin çekilmesiyle gelecekle ilgili (Held\&Cummings, 2013, ss.404-405) son dönemlerde IŞID gibi radikal grupların bölgeyi ve küreyi dini ve mezhepsel radikallikle tehdit etmektedir.

\section{Sonuç Yerine}

ABD 1990'l1 y1llarda güç kullanarak kaosu önlemede dengeleme siyaseti izlerken Bush Doktrini ile son on y1ldır dünyaya yeni bir dizayn verme(savaşdemokrasi ikileminde) siyaseti gütmektedir, Avrupa buna bütünüyle katılmamaktadır (Bağc1, 2004, ss.126-127). İyi huylu hegemonya anlayış1, gücün ve zenginliğin rakipler arasında daha adil dağılımına yol açmış, onlara serbest hareket etme imkânı sağlamış ve nihayetinde, pax-Americana'nın sorgulanmasını beraberinde getirmişti. Teknolojik ve kültürel anlamdaki hegemonyası da zayıflayan ABD'nin elinde başına askeri gücü ve üstünlüğünü bulunuyordu, ama bu güç de sadece havadan ve teknoloji ağırlıklı savaşlara girmekle s1nırlı olarak kullanıldı. 2000'lerde ise ABD'nin bu durumun üstesinden gelinebilmesi, yolunda yeni muhafazakârlar ve Bush yönetimi, yeni bir hegemonik yapıya geçişi kaba kuvvet kullanarak yani askeri yöntemlerle sağlama çabası içerisine girdiler ve Amerika'nın kendisini, değerlerini ve yaşam biçimini savunması için gerektiğinde bu gücün önalıcı biçimde kullanılabileceği açıkça deklare edilmiş oldu.

Diğer bir ifade, ilk başta üretim daha sonra da finans alanlarındaki hakimiyetini zamanla yitirmeye başlayan ABD, Bush yönetimi ile birlikte, zora ve rızaya dayalı boyutlarıyla Gramsci hegemonyanın yeniden üretilmesi ve sürdürülebilmesinde, dengeyi zora dayalı ve ABD'nin sadece kendi çıkarları etrafında şekillenen bir hegemonya lehine değiştirmiş oldu. Hegemonyanın dayandığını normlar, kurumlar ve pratiklere aykırı hareket bir şekilde hareket edip bunları zedeleyerek Washington, öteki devletlerin hegemon güce rizasını onların da çıkarlarını gözetmesi şartı ile verdikleri hususunu dikkate almamaktaydı. Dolayısıyla, çalışmada daha öncede de bahsettiğimiz gibi böyle bir durumda hegemonun meşruiyetini bu şartlar altında kaybedebilmesi söz konusu idi. Bunu, İkinci Körfez Savaşı'na giden yolda ABD yönetiminin müttefikleriyle yaşadığı ciddi görüş ayrılığında, Irak'a komşu ülkelerin savaşa desteğini alma konusunda ki başarısızlığı (Tezkere krizi buna gösterilecek en önemli örneklerden birisidir) da ve savaşın maliyetini tek basına karşılamak zorunda kalmasında bariz bir şekilde gözlemlemek mümkündür.

Afganistan'a meşru müdafaa sebebi ile savaş açmış olan Bush yönetimi, Irak'a karşı ise bunun çok ötesine geçecek bir biçimde önleyici-saldırgan savaşa başvurma yoluna gitmiş ve meşruiyet kaygısı gütmeden hareket etmiş- 
tir. Afganistan'a gerçekleştirilen operasyon direkt olarak 11 Eylül'e verilmiş bir karşıllk iken, önleyici bir müdahale şeklinde nitelendirilen Irak Savaş'ını bu kapsamda değerlendirilmesi mümkün gözükmemektedir. Afganistan ve Irak'ta askeri açıdan ABD açısından olumlu sonuçlar alınmış olsa da Bush Doktrini'nin savaş sonrasında iki ülkenin yeniden yapılandırılması ve istikrara kavuşturulması noktasında başarısız olduğu barizdir.

Öteki uluslar üzerinde belli bir siyasi denetimin kurulması ve geçici toprak işgaline gidilmesi anlamında öyleyse, ABD’nin 11 Eylül sonrası gerçekleştirdiği faaliyetlerinde özellikle Irak operasyonunda gayri-resmi ve dolaylı yollara başvuran farklı bir Hegemon güç görünümü arz ettiği söylenebilir. Hegemonyasının temelleri çatırdamaya başlayan $\mathrm{ABD}$, bunu sadece askeri açıdan üstün durumda olması ile bir farklı bir imparatorluğa dönüşerek aşmaya çalışmıştır. Ama mevcut imkânları günümüz dünyasında bunu gerçekleştirme açısından yetersiz kalacağından, öteki ulusların rızasına dayalı hegemonyadan tam anlamda bir kopuşun gerçekleşmesi mümkün gözükmemektedir. Dolay1sıyla, pax-Americana'nın sürekliliği içinde, imparatorluğu geçiş çabası sadece geçici bir aşama olarak görülebilir. Karşılıklı bağımlılık, çok taraflı rejimler ve küreselleşme çağında, sadece zora dayalı bir imparatorluk inşa etmeye çalışmak ütopik bir yaklaşım olacaktır. ABD'nin ulaşmak istediği, mevcut hegemonyasının dayandığı kurallar bütününü, Amerikan çıkarları ekseninde kökten bir değişime uğratmaktır. Ama bu, hegemonyanın ilelebet süreceği anlamına gelmemektedir; nitekim, tarihsel olarak baktığımızda her hegemonik sistemin kaçınılmaz bir şekilde kendi karşıtını yarattı̆ğna şahit olmaktayız.

Gramscici anlamda sosyal güçler, devlet ve dünya düzeni arasındaki eklemlenmeye dayalı hegemonya tanımı karşısında, imparatorluk söylemi, sosyal güçleri devre dışı bırakan, tek merkezden yönetilip hâkimiyet kuran bir güç algılamasına dayanmaktadır. İmparatorluğun tek bir merkezden tüm tahakküm altındakilerin devletlerin yönetilmesi şekilde nitelendirilmesi halinde, bunu tam manasıyla gerçekleştiremeyen Amerika'yı bir imparatorluk olarak nitelendirmek mümkün gözükmemektedir. ABD'nin öteki ulusların da üzerinde uzlaştığı bu şekilde kapsamlı bir hükümranlık sistemi kurması halinde ise zaten bir imparatorluktan değil, bu sistemin rızaya ve meşruiyete dayalı olması dolayısıyla sadece hegemonyadan söz etmek gerekecektir. 


\section{KAYNAKÇA}

Juliet Kaarbo ve James Lee Ray, Global Politics, Boston:Wadsworth, 2011, s.187.

Stephen R.Gill, American Hegemony and the Trilateral Commission, Cambridge University Press, 1990.

"Irak'ta Savaşa Hayır" etkinlikler programı, http://www.savaskarsitlari.org/arsiv.asp?Arsiv TipID=9\&ArsivAnaID=11634 erişim 17.06.2014

“Empire”, Ingilizce-Türkçe Redhouse Sözlüğ̈̈, İstanbul:Redhouse Yayınevi, 1995, s.311..

“Imperialism”, Martin Griffiths ve Terry O'Callaghan, International Relations: The Key Concepts, Routledge, 2004, s.152.

A. F. K. Organski, "The Power Transition”, İçinde Jhon A. Vasquez, Classiscs of International Relations, NewJersey:Prentice Hall, 1996, s.306.

A. Raşit Kaya, “Adını Koyalım: Tutmayan Hegemonya”, Der. E. Fuat Keyman, Liberalizm, Devlet, Hegemonya, Everest, 2002, ss.4-8.

Andrew Linklater, "Marx ve Marxizm”, İçinde Der. Scott Burchill vd. Uluslararası İlişkiler Teorileri, Çev. Ali Aslan, Küre Yayınları, 2012, ss.151-182.

Anthony Sampson, Günümüzde Petrol Oyunu, Çev. Aziz Üstel, Altın Kitaplar, 1976, ss.320-321.

Atilla Eralp (der), Devlet ve Ötesi: Uluslararası İlişkilerde Temel Kavramlar, İstanbul, İletişim, 2005, ss. 155-157.

Berdal Aral, Uluslararası Hukukta Meşru Müdafaa Hakkı, Ankara:Siyasal Kitabevi, 1999, Ss. $1-5$.

Beverlay Milton Edwards, Contemporary Politics in the Middle East, Polity, 2011, ss.260267.

Bill Ashcroft, Garet Griffiths ve Helen Tiffin, The Post-Colonial Studies:Reader, NewYorkLondon, Routledge,2002.

Bob Jessop, Devlet Teorisi: Kapitalist Devleti Yerine Oturtmak, Çev. Ahmet Özcan, Ankara:Epos Yayınları, 2008, ss.279.

Chalmers Johnson, Amerikan Emperyalizminin Son Baharl, Hasan Kösebalaban (Çev.), İstanbul: Küre Yayınları, 2005, ss. 253-254

Christopher Chase-Dunn, Peter Taylor, Giovanni Arrighi, ve devam1.... "Hegemony and Social Change," Mershon International Studies Review, Vol. 38, No. 2 (Oct., 1994), pp, Ekim 1994, s. 373.

Colbert C. Held ve John Thomas Cummings, Middle East Patterns: Places, Peoples and Politics, ss.404-405.

Daniel Brumberg, "Between Realism and Wilsonianism: The U.S. and The Muslim World after Iraq", İçinde Der. Daniel Brumberg ve Dina Shehata, Conflict, Identity, and Reform in the Muslim World: Challenges for U.S. Engagement, Washington:US Institute of Press, 2009, ss.389-394.

Deniz Ülke Arıboğan, “Güvenliksiz Barıştan, Barışsız Güvenliğe,” Der.Toktamıs Ateş, ABD Dıs Politikasında Yeni Yönelimler ve Dünya, Ankara, Ümit Yayınc1lık, 2004, s. 50. 
Edward Said, Oryantalizm: Sömürgeciliğin Keşif Kolu, Çev. Selahaddin Ayaz, Pınar Yayınlar1, 1991, s.18.

Ergin Yıldızoglu, Hegemonyadan İmparatorluğa, İstanbul, Everest Yayınları, 2003.

F. Gregory Gause, “The International Politics of the Gulf”, İçinde Louise Fawcett, International Relations of the Middle East, Oxford University Press, 2009, ss.285-286.

Fatma Taşdemir, , Uluslararası Terörizme Karşı Devletlerin Kuvvete Başvurma Yetkisi, USAK, 2006, ss.159-160.

Frances Fox Piven, "Globalizing Capitalism and the Rise of Identity Politics, Socialist Register, 1995, ss.102-116. İçinde Richard Little ve Michael Smith, Perspectives on World Politics, Rooutledge, 2006, ss.278-285.

G. Jhon Ikenberry, "Is American Multilateralism in Decline”, İçinde Der. Karen A. Mingst ve Jack L. Snyder, New York, Essential Readings in World Politics, 2004, ss.262-282.

Graham F. Fuller, İslamsız Dünya, Çev. Hasan Kaya, Profil, 2010-2013, ss.282-283.

Hakan Tunç, "Preemption in the Bush Doctrine:A Reappraisal" Foreign Policy Analysis, Vol. 5, No. 1, 2009, ss. 1-16.

Hasan Ünal, “Türkiye-Irak: Irak Savaşı, Türk Amerikan İlişkilerinde Irak Krizi, Irak’ın Geleceği”, Der. Ali Ahmetbeyoğlu, Hayrullah Cengiz vd., Irak Dosyası, İstanbul:Tarih ve Tabiat Vakfi, 2003, s.309.

Henry Kissenger, Diplomasi, Çev.İbrahim H. Kurt, İş Bankası, 2011, ss.9-10.

Howard Zinn, Amerika Birleşik Devletleri Halklarının Tarihi, Çev. Sevinç S. Özer, İmge Kitabevi, 2005, s.316.

Hüseyin Bağcı, Savaş ve Demokrasi, Gazeteciler ve Yazarlar Vakfı Yayınları, 2004, ss.126127.

Hüseyin Pazarc1, Uluslararası Hukuk, Ankara:Turhan Kitabevi, 2010, ss.521-522.

Immanuel Wallerstein, "The Rise and Future Demise of the World Capitalist System: Concepts for Comparative Analysis", Comparative Studies in Society and History, Vol.16, no.4, 1974, ss.387-413. İçinde Karen A. Mingst ve Jack L. Snyder, Essential Readings in World politics, NewYork, Norton, 2004, ss.130-137.

James L. Richardson, "The Ethics of Neoliberal Institutionalism”, İçinde Christian ReusSmit ve Duncan Snidal, International Relations, Oxford, 2010, s.223.

James Petras ve Henry Veltmeyer, "The Dynamics of Anti-Globalization”, Richard Little ve Michael Smith, Perspectives on World Politics, Routledge, 2006, ss.323-324.

Jennifer Sterling Folker, "Neoliberalism", İçinde Der. Tim Dunne, Milja Kurki ve Steve Smith, International Relations Theories: Discipline and Diversity, Oxford, 2013, ss.114-131.

Jhon A. Hobson, “The Economic Taproot of Imperialism”, Paul R. Viotti ve Mark V. Kauppi, International Relations Theory: Realism, Pluralism, Globalism, NewYork:Macmillian, 1999, ss.365-368.

Jhon Baylis ve Steve Smith, The Globalization of World Politics: An Introduction to International Politics, Oxford University Press, 2006, ss.95, 773-774.

Johan Galtung, “A Structural Theory of Imperialism”, Journal of Peace Research, Vol.13, no.12, 1971, ss.81-94. İçinde Der. Jhon A. Vasquez, Classics of International Relations, Prentice Hall, 1996, ss.265-273..

John J.Mearsheimer, The Tragedy of Great Power Politics, First Edition, New York: Norton Press, 2001, s.1 
Johnson, C. (2005) Amerikan Emperyalizminin Son Baharı, (Çev. H. Kösebalaban), İstanbul: Küre Yayınları, ss. 253-254. 11 .

Joseph Nye, Amerikan Gücünün Paradoksu, İstanbul, Literatür Yayınc1lı, 2003b, s. 10-

Joseph S. Nye, Understanding International Conflicts: Theory and Practice, NewYork:Pearson, 2003a, s.60.

Joshua S. Goldstein ve Jon C. Pevehouse, International Relations, Pearson, 2013, s.59.

Juliet Kaarbo ve James Lee Ray, Global Politics, Boston:Wadsworth, 2011, s.192. s:332

Kurtbağ, Ömer. (2010) Amerikan Yeni Sağı ve Dış Politikası, USAK Yayınları, Ankara.

Marcelo G. Kohen, “ABD’nin Soğuk Savaşın Bitişinden Sonra Kuvvet Kullanması ve Bunun Uluslararası Hukuka Etkisi”, ABD Hegemonyası ve Uluslararası Hukukun Temelleri, Ed. Michael Byers, George Nolte, Çev. Ed. Erdem Denk, Ankara: Siyasal Basın Yayım Dağıtım, 2007,s.226.

Michael C. Hudson, The United States in the Middle East, İçinde Louise Fawcett, International Relations of the Middle East, Oxford University Press, 2009, s.327.

Mustafa Özcan, “Irak’ta Direnişin İslami Veçhesi”, İçinde Der. Ali Ahmetbeyoğlu, Hayrullah Cengiz vd., Irak Dosyast, Tarih ve Tabiat Vakfi, 2003, s.271.

Mustafa Özel, "Kapitalist Hegemonyadan Küresel İmparatorluga,” Anlayıs, Say1 1 (Haziran 2003), ss.12-19.

Mustafa Tekin Taşkun, Babil Düşerken: Bir Ülke Nasıl Yutulur, Q-Matris Yayınları, 2004, s.517.

Nicolas Pelham, A New Muslim Order:The Shia and Middle Eastern Sectarian Crises, Plagrave Macmillian, 2008, ss.117-118.

Ömer Kurtbăg, ''Eleştirel Uluslararası İlişkiler Yaklaşımları Çerçevesinde Amerikan Dış Politikasının Analizi Hegemonya Söylemi ve Amerikan Muhafazakar Sağı”, Yayınlanmamış Doktora Tezi, Ankara, 2007. 57.

Paul Harrison, 3. Dünyanın Batılılaştırılması, Çev. Cevdet Cerit, Pınar Yayınları, 1991,ss.39-

Peter Childs ve Patrick Williams, An Introduction to Post-Colonial Theory, Pearson Education, 1997, s.33.

Peter Gowan, "Neoliberal Cosmopalitanism”, New Left Review, Vol.11, Sep-Oct 2001, ss.79-93. İçinde Richard Little ve Michael Smith, Perspectives on World Politics, Rooutledge, 2006, ss.270-277.

Philip Robins, "The War for Regime Change in Iraq", İcinde Louise Fawcett, International Relations of the Middle East, Oxford University Press, 2009, ss.291-293.

Robert Gilpin, Global Political Economy: Understanding International Economic Order, New Jersey:Princeton University Press, 2001, ss.93-97.

Robert J. Lieber, The American Era: Power and Strategy fort he 21st Century, Cambridge, 2005, s.42.

Robert O.Keohane, After Hegemony, Cooperation and Discord in the World Political Economy, First Edition, New Jersey:Princeton University Press, 1984, s.31

Robert W. Cox ve H. K. Jacobson, “Decisionmaking”, International Social Science Journal, Vol.29, No.1, 1977, ss. 127 
Robert W. Cox, "Social Forces, States and World Orders: Beyond International Relations Theory", Millenium: Journal of International Studies, Vol.10, no.2, 1981, ss.126-155. İçinde Der. Jhon A. Vasquez, Classics of International Relations, New Jersey: Prentice Hall, 1996, ss.126-134.

Ronald Kramer, Raymond Michalowski ve Dawn Rothe, "The Supreme International Crime": How the U.S. War in Iraq Threatens the Rule of Law", Social Justice, 2005, Cilt: 32, Say1: 2, s. 59.

Ropert Gilpin, War and Change in World Politics, First Edition, Cambridge: Cambridge University Press, 198, s.203

Sienho Yee, "The Potential Impact of the Possible US Responses to the 9-11 Atrocities on the Law regarding the Use of Force and Self-defence", Chinese Journal of International Law, 2002, Cilt: 1, s. 292.

Stephen R. Gill, Power and Resistance in the New World Order, s. 86

Susan Strange, "The Future of American Empire", Journal of International Affairs, Vol.42, No.1, 1988, 1-17. İçinde Richard Little ve Michael Smith, Perspectives on World Politics, Routledge, 2006, ss.352-358.

Susan Strange, States and Markets, London:Pinter Publishers, 1994, ss.23-119.

Tayyar Arı, Uluslararası İlişkiler ve Dış Politika, Bursa: MKM Yayıncılık, 2008, ss.303310 .

Tayyar Arı, "Türkiye, Irak Ve Abd: Soğuk Savas Sonrasi Dönemde Basra Körfezi'nde Yeni Parametreler", http://www.tayyarari.com/download/Turkiye irak abd.doc, Erişim tarihi 20.05.2014

Tayyar Arı, Uluslararası İlişsiler Teorisi, İstanbul:Alfa Yayınları, 2006, s.227.

Theodore H. Cohn, Global Political Economy. Theory and Practice, Longman, 2003, s.27.

Torbjorn L. Kunetsen, History of International Relations Theory, Manchester University, 1992, ss.171-172.

Ümit Özdağ, "Yeniden Yapılanan Ortadoğu”, İçinde Der. Ali Ahmetbeyoğlu, Hayrullah Cengiz vd., Irak Dosyasl, Tarih ve Tabiat Vakfi, 2003, s.150.

Vassilis K. Fouskas ve Bülent Gökay, The New American Imperialism: Bush's War on Terror and Blood for Oil, Connecticut:Praeger Security International, 2005, s.14. İçinde Emre İseri, The US Grand Strategy and the Eurasian heartland in the 21th century:with reference to the main Caspian oil export pipeline BTC, PhD Thesis, Keele University, 2008, s.134. Unpublished Thesis.

Walter C. Opello, ve Stephen J. Rosov, The Nation State and Global Order: A Historical Introduction to Contemporary Politics, London: Lynne Rienner Publishers, 2004, s.167.

Yunus AKGÜR ve Ertan ÇAKIROĞLU, "Şangay İşbirliği Örgütü” KÖKSAV E-Bülteni, KÖK Sosyal ve Stratejik Araştırmalar Vakfi (KÖKSAV), Nisan 2008, s.3.

"Hegemony", İngilizce-Türkçe Redhouse Sözlüğü, İstanbul:Redhouse Yayınevi, 1995, s.452.

"Hegemonya”, Osmanlıca Türkçe Ansiklopedik Büyük Lügat, İstanbul:Türdav, 1993, s.360.

A. Ercan Su, 'Elestirel Teori Çerçevesinde Hegemonya ve Alt-Hegemonya: Almanya ve Japonya Örneği”, Yayınlanmamış Doktora Tezi, Ankara Üniversitesi, Ankara, 2006. 
Joshua S. Goldstein ve Jon C. Pevehouse, International Relations, Pearson, 2013, ss. 58,506 .

Martin Griffiths ve Terry O'Callaghan, International Relations: The Key Concepts, London: Routledge, 2004, ss.137-138.

Mehmet Yetiş, "Hegemonya", İçinde Der. Gökhan Atılgan ve Attila Aytekin, Siyaset Bilimi: Kavramlar, İdeolojiler, Disiplinlerarası İlişkiler, Yordam Kitap, 2012, s.87.

Robert O.Keohane, After Hegemony, Cooperation and Discord in the World Political Economy, First Edition, New Jersey:Princeton University Press, 1984, s.34

Türk Dil Kurumu Web Sitesi, http://www.tdk.gov.tr/ 